\title{
Differential glycosylation of envelope gp120 is associated with differential recognition of HIV-1 by virus-specific antibodies and cell infection
}

Milan Raska ${ }^{1,2^{*}}$, Lydie Czernekova ${ }^{1}$, Zina Moldoveanu ${ }^{2}$, Katerina Zachova ${ }^{1}$, Matt C Elliott ${ }^{2}$, Zdenek Novak $^{8}$, Stacy Hall ${ }^{2}$, Michael Hoelscher ${ }^{3}$, Leonard Maboko ${ }^{4}$, Rhubell Brown ${ }^{2}$, Phillip D Smith ${ }^{5,6}$, Jiri Mestecky ${ }^{2,5,7}$ and Jan Novak ${ }^{2 *}$

\begin{abstract}
Background: HIV-1 entry into host cells is mediated by interactions between the virus envelope glycoprotein (gp120/gp41) and host-cell receptors. N-glycans represent approximately 50\% of the molecular mass of gp120 and serve as potential antigenic determinants and/or as a shield against immune recognition. We previously reported that N-glycosylation of recombinant gp120 varied, depending on the producer cells, and the glycosylation variability affected gp120 recognition by serum antibodies from persons infected with HIV-1 subtype B. However, the impact of gp120 differential glycosylation on recognition by broadly neutralizing monoclonal antibodies or by polyclonal antibodies of individuals infected with other HIV-1 subtypes is unknown.

Methods: Recombinant multimerizing gp120 antigens were expressed in different cells, HEK 293T, T-cell, rhabdomyosarcoma, hepatocellular carcinoma, and Chinese hamster ovary cell lines. Binding of broadly neutralizing monoclonal antibodies and polyclonal antibodies from sera of subtype A/C HIV-1-infected subjects with individual gp120 glycoforms was assessed by ELISA. In addition, immunodetection was performed using Western and dot blot assays. Recombinant gp120 glycoforms were tested for inhibition of infection of reporter cells by SF162 and YU.2 Env-pseudotyped R5 viruses.

Results: We demonstrated, using ELISA, that gp120 glycans sterically adjacent to the V3 loop only moderately contribute to differential recognition of a short apex motif GPGRA and GPGR by monoclonal antibodies F425 B4e8 and 447-52D, respectively. The binding of antibodies recognizing longer peptide motifs overlapping with GPGR epitope (268 D4, 257 D4, 19b) was significantly altered. Recognition of gp120 glycoforms by monoclonal antibodies specific for other than V3-loop epitopes was significantly affected by cell types used for gp120 expression. These epitopes included CD4-binding site (VRC03, VRC01, b12), discontinuous epitope involving V1N2 loop with the associated glycans (PG9, PG16), and an epitope including V3-base-, N332 oligomannose-, and surrounding glycans-containing epitope (PGT 121). Moreover, the different gp120 glycoforms variably inhibited HIV-1 infection of reporter cells.

Conclusion: Our data support the hypothesis that the glycosylation machinery of different cells shapes gp120 glycosylation and, consequently, impacts envelope recognition by specific antibodies as well as the interaction of HIV-1 gp120 with cellular receptors. These findings underscore the importance of selection of appropriately glycosylated HIV-1 envelope as a vaccine antigen.
\end{abstract}

Keywords: gp120 glycosylation, Glycan-specific antibody, Deglycosylation resistance, Neutralization inhibition

\footnotetext{
*Correspondence: raskamil@uab.edu; jannovak@uab.edu

'Department of Immunology, Palacky University in Olomouc, 77100

Olomouc, Czech Republic

${ }^{2}$ Department of Microbiology, University of Alabama at Birmingham,

Birmingham, AL 35294, USA

Full list of author information is available at the end of the article
}

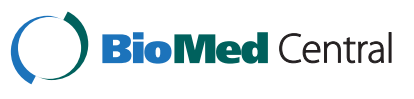

(c) 2014 Raska et al.; licensee BioMed Central Ltd. This is an Open Access article distributed under the terms of the Creative Commons Attribution License (http://creativecommons.org/licenses/by/4.0), which permits unrestricted use, distribution, and reproduction in any medium, provided the original work is properly credited. The Creative Commons Public Domain Dedication waiver (http://creativecommons.org/publicdomain/zero/1.0/) applies to the data made available in this article, unless otherwise stated. 


\section{Background}

The HIV-1 envelope glycoprotein (Env), a trimer of gp120/gp41, is the relevant target for neutralizing antibodies [1-9]. Such antibodies may limit disease progression, as shown for elite neutralizers whose antibodies exhibit strong and broadly neutralizing activity in vitro [9-12]. However, efforts to generate Env-based vaccines have had limited success [13-16] due to the high variability of the env gene. For the gp120 subunit, $\mathrm{N}$-glycans contribute approximately $50 \%$ of the total molecular mass [17]. The viral genome determines the potential attachment sites of the $N$-glycans (specific amino-acid motifs N-X-S/T), whereas the biosynthetic machinery of the host cells producing the virus profoundly determines the composition of the Env glycans [18-20].

We previously reported that glycosylation of gp120 was affected by the cell type and metabolic activity of the producer cells, resulting in distinct gp120 N-glycan content and heterogeneity [21]. Notably, gp120 produced in T cells contains mostly high-mannose and hybrid $\mathrm{N}$-glycans with fewer complex $N$-glycans compared with gp120 produced in other cell types, such as hepatocytes, which contains a higher proportion of complex $\mathrm{N}$-glycans in addition to high-mannose $\mathrm{N}$-glycans. The recombinant gp120 produced in T cells, B cells, and HEK 293T cells has extensive heterogeneity of complex $\mathrm{N}$-glycans [21]. Moreover, celltype specific $\mathrm{N}$-glycosylation of gp120 affects the binding by antibodies from sera of subjects infected with subtype B HIV-1 [21], results that extend previous work on cellspecific HIV-1 Env glycosylation [17,18,22-28].

HIV-1 attachment to and entry into a host cell requires interaction between viral Env and the host cell CD4 receptor and CCR5 or CXCR4 co-receptor [20,29,30]. Env glycans influence these interactions [31-35] and, thus, impact HIV-1 infectivity [36,37]. In this regard, the vaccine trial RV144 identified a potentially protective epitope of HIV-1 Env in the gp120 V1/2 loop [38,39] and V1/2 loop glycan (N160) that contributes to formation of a quarternarystructure epitope recognized by new class of broadly neutralizing monoclonal antibodies of PG family $[10,40]$. Although glycans influence protein folding, potentially affecting the conformation of surface-exposed epitopes involved in antibody binding, $\mathrm{N}$-glycans also serve as epitopes or part of epitopes for some broadly neutralizing antibodies [40-54]. Conversely, gp120 glycans may serve as a "shield" against neutralizing antibodies [44,55-57]. For example, in late-stage HIV-1 infection, escape variants with env gene sequences that encode additional or deleted potential $\mathrm{N}$-glycosylation sites (PNGS) promote resistance to neutralizing antibodies $[4,31,32,58-69]$.

In this manuscript, we show that the binding of broadly neutralizing monoclonal antibodies to native, recombinant oligomeric gp120 was determined by the producing cellspecific differential glycosylation. A partial removal of
$N$-glycans from gp120 increased the binding of some gp120-specific monoclonal antibodies, as well as polyclonal serum antibodies from persons infected with HIV-1 subtype A/C. Conversely, the binding of several other gp120-specific monoclonal antibodies was reduced. Moreover, the different gp120 glycoforms variably inhibited HIV-1 infection of reporter cells, depending on cell-specific glycosylation. Thus, our data support the hypothesis that the glycosylation machinery of cells that produce HIV-1 Env shapes gp120 glycans and, consequently, impacts antibody reactivity as well as virus infectivity. Therefore, it is important in the design of HIV-1 vaccines to take into account the differential glycosylation of gp120.

\section{Results}

Glycosylation of gp120 affects recognition by gp120-specific neutralizing and non-neutralizing monoclonal antibodies

To elucidate the role of Env glycans in binding of gp120 by HIV-1-specific antibodies, we evaluated the binding of recombinant gp120 produced in four cell lines (HEK 293T, Jurkat, HepG2, and CHO) representing four differentially glycosylated gp120 variants [21].

Western blot detection after SDS-PAGE separation of denatured and reduced gp120 preparations was performed using two broadly neutralizing (2G12 and b12) and five variably neutralizing (268 D4, F425 B4e8, 257 D4, 447-52D, 19b) HIV-1-specific monoclonal antibodies (Table 1). As shown in Figure 1A, four of the six antibodies (257 D4, 447-52D, and 19b specific to V3 loop, and 2 G12 is specific to Man $\alpha 1,2 \mathrm{Man})$ exhibited clearly visible differences in binding to four gp120 glycoproteins. These data suggested that differential $\mathrm{N}$-glycosylation impacted antibody access to the neighboring peptide-based Env epitopes even in denatured and reduced gp120 glycoproteins. The relative differences in antibody binding to the glycoproteins evaluated by densitometric analysis of two independent Western blots are shown in Figure 1B. Notably, gp120 from $\mathrm{CHO}$ cells was only marginally recognized by the four antibodies (257 D4, 447-52D, 19b, 2G12), whereas gp120 from HepG2 was preferentially recognized by all tested monoclonal antibodies. Monoclonal antibody b12, which detects a conformational peptide epitope, does not react with gp120 in SDS-PAGE Western blot, and thus served as a negative control.

Furthermore, we evaluated the binding of HIV-1specific monoclonal antibodies to native recombinant gp120 produced in HEK 293T, Jurkat, RD, HepG2, and $\mathrm{CHO}$ cells using ELISA. Ten of the twelve antibodies (268 D4, 257 D4, 19b, 2G12, b12, PGT121, PG16, PG9, VRC03 and VRC01) demonstrated significant differences in binding to individual gp120 glycoforms (ANOVA, $\mathrm{P}<0.02$ ) (Figure 2), confirming the effect of $\mathrm{N}$-glycans on the presentation and/or accessibility of the Env epitopes. No 
Table 1 Epitope specification of tested monoclonal antibodies

\begin{tabular}{|c|c|c|c|c|c|c|c|}
\hline Monoclonal antibody & Epitope structure & Epitope & $\begin{array}{l}\text { Direct involvement } \\
\text { of glycans in epitope } \\
\text { formation }\end{array}$ & $\begin{array}{l}\text { Different reactivity } \\
\text { with individual } \\
\text { gp120 glycoforms* }\end{array}$ & $\begin{array}{l}\text { Glycan-shielding } \\
\text { effect** }\end{array}$ & $\begin{array}{l}\text { Dilution corresponding } \\
\text { to linear range in } \\
\text { ELISA ( } \mu \mathrm{g} \text { per } \mathrm{ml})^{*}\end{array}$ & References \\
\hline $268 \mathrm{D} 4$ & V3 loop tip HIGPGR & linear & - & + & + & 0.03 & {$[51,70]$} \\
\hline 257 D4 & V3 loop stem KRIHI & linear & - & + & + & 0.01 & {$[51,70]$} \\
\hline F425 B4e8 & V3 loop tip involving GPGRA, $\| e^{309}$, and Phe $\mathrm{P}^{317}$ & linear & - & - & + & 0.04 & {$[52,71]$} \\
\hline $447-52 D$ & $\begin{array}{l}\text { V3 loop tip GPGR plus amino acids at } \\
\text { N-terminal segment of the V3 }\end{array}$ & conformational & - & - & + & 0.07 & {$[72,73]$} \\
\hline $19 b$ & V3-loop tip -I_-G-FY-T & linear & - & + & + & 0.01 & [74] \\
\hline 2G12 & $\begin{array}{l}\text { Man a1,2 Man-containing oligo-mannose } \\
\quad \mathrm{N} \text {-glycans on } \mathrm{C} 2, \mathrm{C} 3, \mathrm{~V} 4 \text {, and } \mathrm{C} 4\end{array}$ & conformational & + & + & + & 0.04 & {$[75,76]$} \\
\hline PGT 121 & $\begin{array}{l}\text { V3 base together with multiple surrounding } \\
\text { glycans }\end{array}$ & conformational & + & + & - & 0.15 & [77] \\
\hline PG16 & $\begin{array}{l}\text { Epitope dependent on several glycosylation } \\
\text { sites in the V1, V2, V3 loop mostly high-mannose }\end{array}$ & conformational & + & + & - & 7 & {$[45,78]$} \\
\hline PG9 & $\begin{array}{l}\text { Epitope dependent on several glycosylation sites } \\
\text { in the V1, V2, V3 loop mostly high-mannose }\end{array}$ & conformational & + & + & - & 6 & {$[45,78]$} \\
\hline b12 & CD4 binding site & conformational & - & + & - & 0.01 & {$[79,80]$} \\
\hline VRC03 & CD4 binding site & conformational & - & + & - & 7 & {$[81,82]$} \\
\hline VRC01 & CD4 binding site & conformational & - & + & + & 0.15 & {$[81,82]$} \\
\hline
\end{tabular}

*This study, conclusions based on the differences in mAb binding to individual gp120 glycoforms; ** this study, conclusion based on the partial $N$-glycan removal effect on mAb binding. 


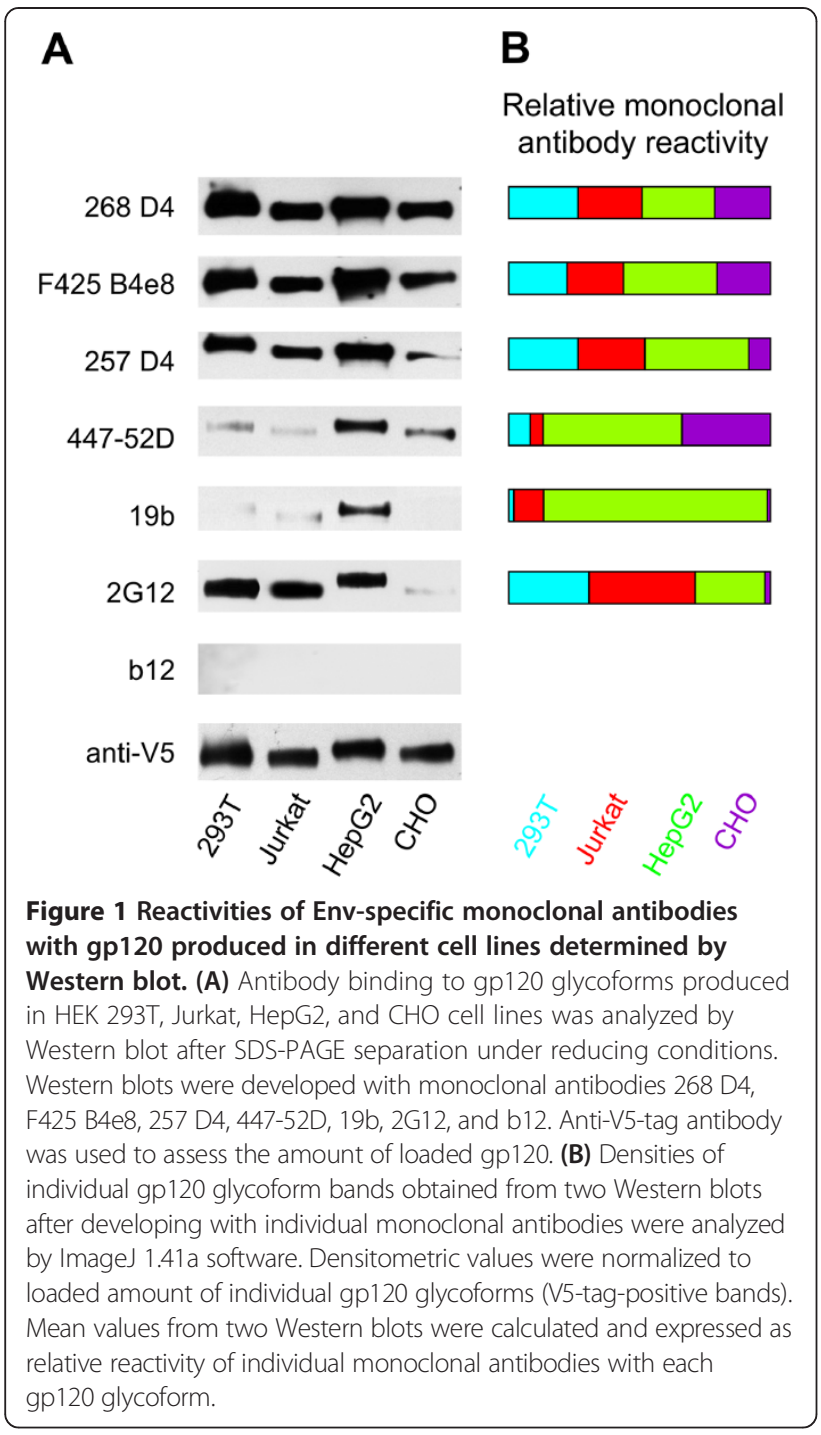

significant differences in the binding of the remaining two antibodies (F425 B4e8 and 447-52D; ANOVA, P > 0.17 ) to the tested gp120 preparations were observed. As the antibodies F425 B4e8 and 447-52D recognize short linear epitope GPGRA and GPGR, respectively, on the apex of gp120 V3 loop [53], the data suggest that those epitopes are not significantly affected by heterogeneity of sterically adjacent glycans. GPGR-containing epitope is recognized also by $268 \mathrm{D} 4$ antibody, but this antibody exhibited significant differences in binding to different gp120 glycoforms. Unlike the F425 B4e8 and 447-52D antibodies, 268 D4 antibody recognizes an epitope extended $\mathrm{N}$-terminally and therefore probably more prone to be influenced by adjacent glycans.

Together, these results suggest that variably glycosylated glycans sterically adjacent to the V3 loop only moderately contribute to differential recognition of a short apex motif of V3 loop (GPGR), but they affect more significantly the binding of antibodies specific for a longer peptide motif that overlaps with GPGR epitope. In contrast to V3 apex-recognizing antibodies, recognition of gp120 glycoforms produced by different cell lines by all other tested monoclonal antibodies specific to epitopes, such as CD4-binding site (VRC03, VRC01, b12), discontinuous epitope involving V1/V2 loop with the associated glycans (PG9, PG16), and V3-base-, N332 oligomannose-, and surrounding glycans-containing epitope (PGT121), was significantly affected (ANOVA, $\mathrm{P}<0.01$ ).

The gp120 produced by HepG2 was strongly recognized by five of the twelve monoclonal antibodies (ANOVA, $\mathrm{P}<0.01$ ) of which four antibodies are specific to epitopes close to the apex of V3 loop. Notably, gp120 produced by HepG2 cells, which contained relatively low levels of high-mannose $\mathrm{N}$-glycans [21], reacted strongly with 2G12, indicating that the discontinuous epitope composed of high-mannose $\mathrm{N}$-glycans (Man 1 1,2Man), as well as folding of the protein, are maintained even in gp120 glycoforms with a high proportion of complex $N$-glycans. The gp120 produced by HEK 293T cells (cells commonly used for production of recombinant gp120 and viruses for HIV-1 studies) exhibited the weakest reactivity with most of the tested monoclonal antibodies, except the CD4binding-site-specific antibodies (VRC03 and VRC01) and the V1/V2- and V3-loops and associated glycans-specific antibody (PG16) (ANOVA, $\mathrm{P}<0.01$; Figure 2).

When the binding patterns of the monoclonal antibodies specific to V3 loop apex-containing epitopes determined by Western blot (Figure 1) and ELISA (Figure 2) were compared, the results suggested similar overall dominance in the recognition of gp120 glycoforms from HepG2, although the SDS-denaturation and 2-mercaptoethanol reduction of gp120 during electrophoresis could affect presentation of gp120 epitopes. By comparing the profile for each antibody binding to individual gp120 glycoforms, we found that only $19 \mathrm{~b}$ antibody, specific for the V3 apex, reacted similarly in both Western blot and ELISA. The gp120 glycoforms from $\mathrm{CHO}$ cells were recognized weakly, whereas gp120 glycoforms from HEK 293T cells were well recognized in Western blot although they were among the most weakly recognized gp120 glycoforms in ELISA. Control b12 antibody, which is specific for a multi-peptide conformational epitope [79], did not bind any of the gp120 glycoproteins in the Western blot, due to antigen denaturation, but it reacted strongly with each gp120 in the ELISA. These results suggest that, except of V3 loop apexspecific monoclonal antibodies, the binding of antibodies recognizing epitopes that include CD4-binding site, V1/V2 or V3 base, or specific glycans (such as N160, N332) is dependent on cell-type specific glycosylation of gp120. 


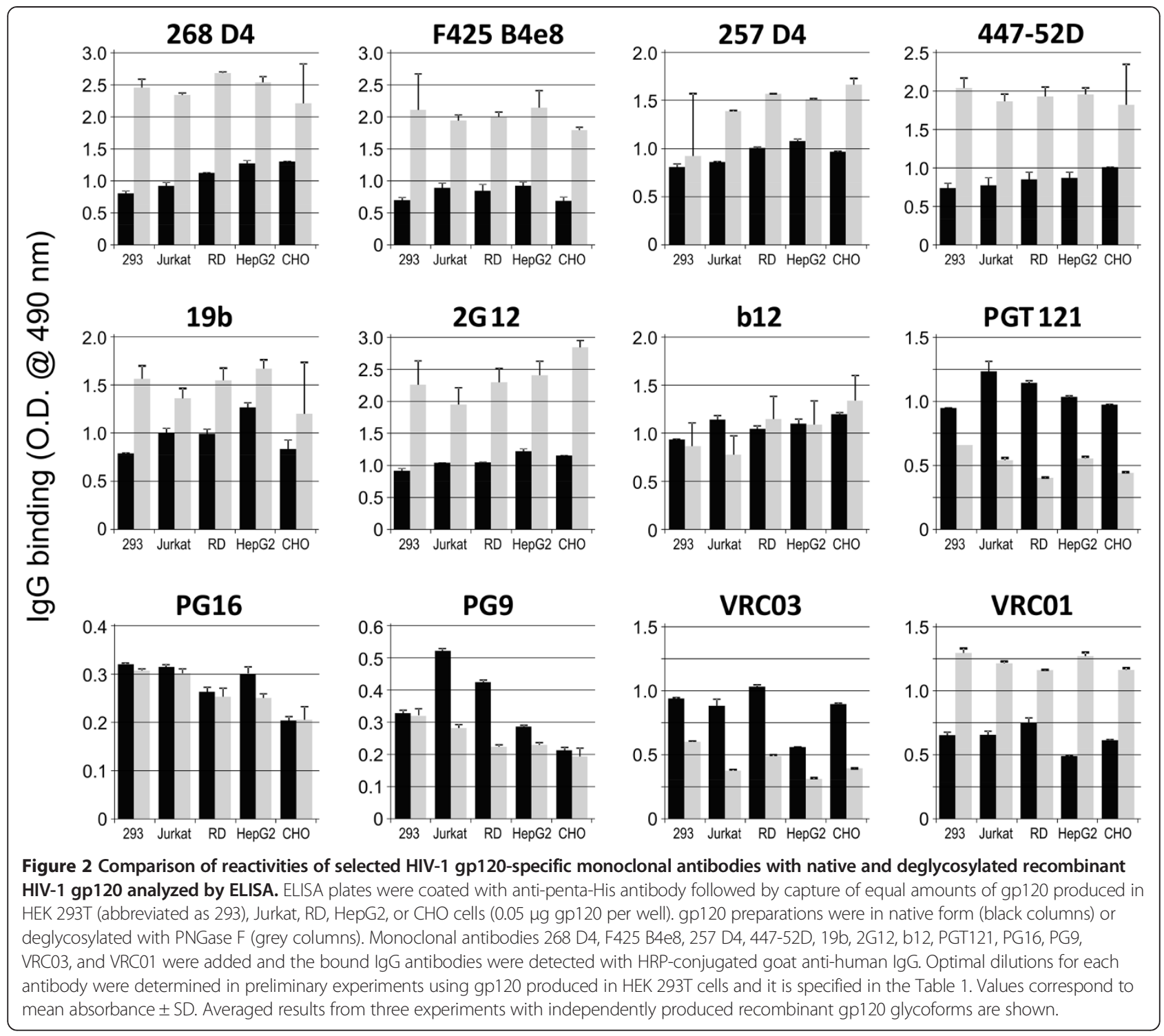

Partial deglycosylation of gp120 affects recognition by some gp120-specific neutralizing and non-neutralizing monoclonal antibodies

Furthermore, we investigated the contribution of Env $N$ glycans to gp120 recognition by monoclonal antibodies by comparing the antibody binding to the native $v s$. deglycosylated gp120 variants. After deglycosylation of individual gp120 variants using $N$-glycanase (PNGase F) under native conditions, the level of deglycosylation of each gp120 protein was confirmed by mobility-shift assay using SDSPAGE Western blot (Figure 3). Deglycosylation under optimized conditions (7.5 IUB PNGase F per $250 \mathrm{ng}$ of gp120 protein) substantially reduced the apparent molecular mass of each glycoprotein from $125-135 \mathrm{kDa}$ to $80-$ $90 \mathrm{kDa}$, indicating that the remaining glycans were resistant to the enzymatic removal under native conditions (Figure 3). Extending the incubation time or increasing PNGase $\mathrm{F}$ concentration did not lead to further reduction of the apparent molecular mass of gp120 on SDS-PAGE Western blot (data not shown).

After enzymatic deglycosylation, the binding of all antibodies, except that of b12, changed significantly for a set of five tested gp120 glycoforms (paired $t$-test, $\mathrm{P}<0.03$ ). The monoclonal antibody b12 reacted equally well with native and deglycosylated gp120 glycoforms indicating that the contribution of glycans removed under native conditions is negligible for this antibody. Deglycosylation enhanced significantly (paired $t$-test, $\mathrm{P}<0.002$ ) the binding reactivity of the V3-loop-specific antibodies (268 D4, F425 B4e8, 257 D4, 447-52D, and 19b) [43,75,83] and CD4binding-site-specific VRC01 antibody [81]. These data suggest that some glycans partially protect gp120 against antibody binding and that the deglycosylation removes this "glycan shield" (Figures 2A, B). Furthermore, after 

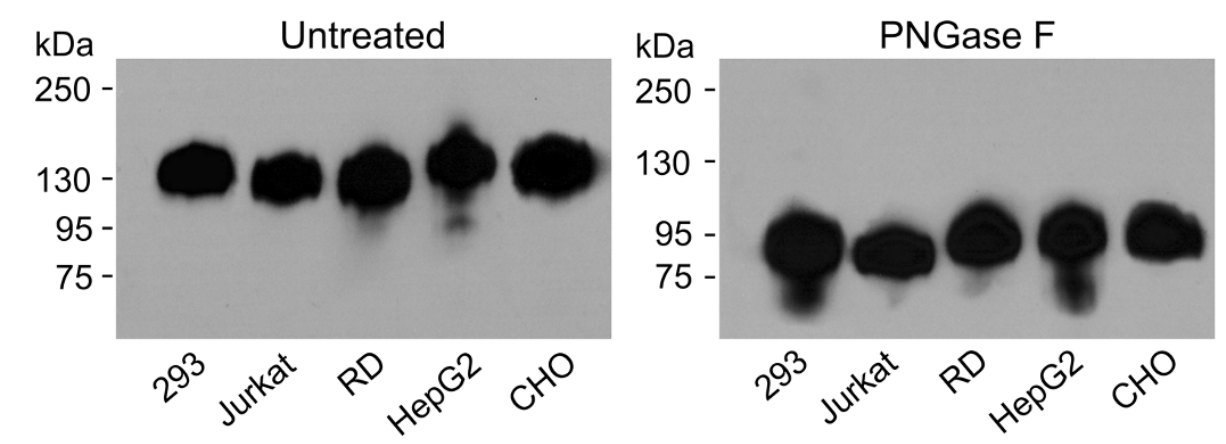

Figure 3 Mobility shift of gp120 after deglycosylation. gp120 glycoproteins produced in HEK 293T, Jurkat, RD, HepG2, and CHO cells were deglycosylated by PNGase F under native conditions, separated by SDS-PAGE under reducing conditions, and detected with anti-V5-tag monoclonal antibody. Change in migration of untreated (left panel) vs. PNGase F-treated (right panel) gp120 preparations was approximately from $130 \mathrm{kDa}$ to $85 \mathrm{KDa}$. Results from one of two experiments are shown.

deglycosylation, the differences in V3-specific monoclonal antibodies reactivities with individual gp120 glycoproteins were not significant. Notably, deglycosylation enhanced more than two-fold ELISA reactivity for $2 \mathrm{G} 12$ (paired $t$ test, $\mathrm{P}<0.001$ ), a monoclonal antibody specific for clusters of Mano1,2Man-linked glycans, indicating that, in agreement with previously published data, the high-mannose glycans involved in the epitope formation are resistant to PNGase F [84,85]. After deglycosylation, 2G12 recognized each of the five gp120 preparations at significantly different magnitudes (ANOVA, $\mathrm{P}<0.007$ ). CHO-produced gp120 antigen was recognized by $2 \mathrm{G} 12$ as the best antigen whereas gp120 produced by Jurkat cells was weakly recognized (Figure 2). Conversely, deglycosylation of gp120 under denaturing conditions resulted in loss of $2 \mathrm{G} 12$ reactivity as detected by Western blot analysis, as all highmannose glycans were removed [21]. Unlike the uniform increase in the reactivity of V3-loop-specific monoclonal antibodies after partial deglycosylation of gp120 (increase ranging from 1.5- to 2.5-fold mean ELISA O.D. values; Figure 2), the reactivity of PGT121 (recognizing V3 base, the N332 oligomannose glycan, and surrounding glycans), decreased after gp120 deglycosylation about 0.5 -fold compared to the untreated protein (paired $t$-test, $\mathrm{P}<0.001$ ), indicating glycan contribution to PGT121 epitope formation. Furthermore, after partial deglycosylation, the variability in PGT121 recognition of individual gp120 glycoforms remained significant (ANOVA, $\mathrm{P}<0.001$ ), leading to conclusion that some surrounding glycans involved in epitope formation are still present. Notably, VRC03 and VRC01 antibodies (recognizing CD4-binding site) exhibited differential changes in their reactivities with individual gp120 glycoforms after partial deglycosylation. The reactivity of VRC03 increased about twice (paired $t$-test, $\mathrm{P}<0.001$ ), whereas that of VRC01 decreased about 0.5 -fold compared to the untreated protein (paired $t$-test, $\mathrm{P}<0.001$ ). The differences in the recognition of individual partially deglycosylated gp120 glycoforms remained significant for
VRC03 (ANOVA, $\mathrm{P}<0.001$ ) and to a lesser extent also for VRC01 (ANOVA, $\mathrm{P}<0.021$ ). This finding suggests that the recognition of CD4-binding sites by VRC03 and VRC01 is differentially affected by adjacent glycans and that some of them contribute to CD4-binding-site epitope (VRC03). Moreover, other glycans may mask the access to CD4-binding site (VRC01). Finally, after partial deglycosylation of gp120, the reactivities of two other monoclonal antibodies, PG16 and PG9 (specific for quaternary epitope composed of the gp120 V1/V2 and V3 loops and associated glycans), decreased (paired $t$-test, $\mathrm{P}<0.03$ ), although the change was more pronounced for PG9 (Figure 2). The differences in reactivities of PG antibodies remained significant for both PG16 and PG9 (ANOVA, P $<0.004$ ). The most pronounced decrease in PG9 reactivity was observed after deglycosylation of gp120 expressed in T-cell line Jurkat and rhabdomyosarcoma cell line RD. Both cell types are known to produce gp120 with high content of high-mannose glycans [21].

\section{Glycosylation of gp120 affects the binding of HIV-1- specific serum antibodies to gp 120}

Having previously shown that binding of polyclonal antibodies from persons infected with HIV-1 subtype B can differentiate the variably glycosylated gp120 preparations [21], here we investigated the binding of antibodies from sera of individuals infected with HIV-1 subtype A/C to gp120 glycoforms either under denaturing (Western blot) or non-denaturating (dot blot and ELISA) conditions. Serum antibodies from nine subjects infected with clade $\mathrm{A} / \mathrm{C}$ virus displayed variable recognition of gp120 according to their glycosylation (Figures 4 and 5). Significant differences were observed between SDS-PAGE Western blot (Figure 4A) and dot blot (Figure 4B) in the recognition of specific gp120 glycoforms by antibodies from individual sera. The relative serum antibody reactivities determined densitometrically are presented in Figures $4 \mathrm{C}$ and D. Overall differences in recognition of 


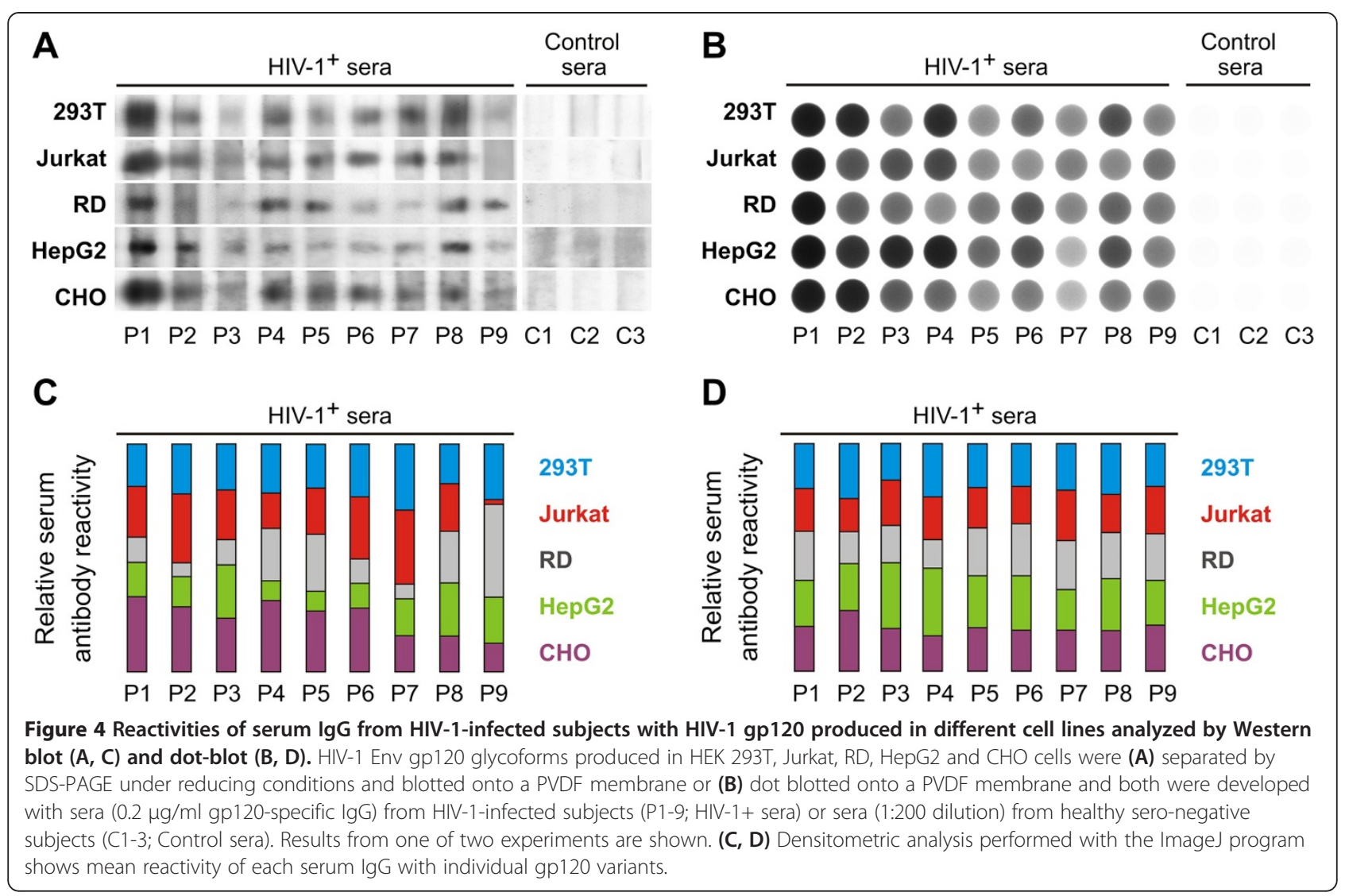

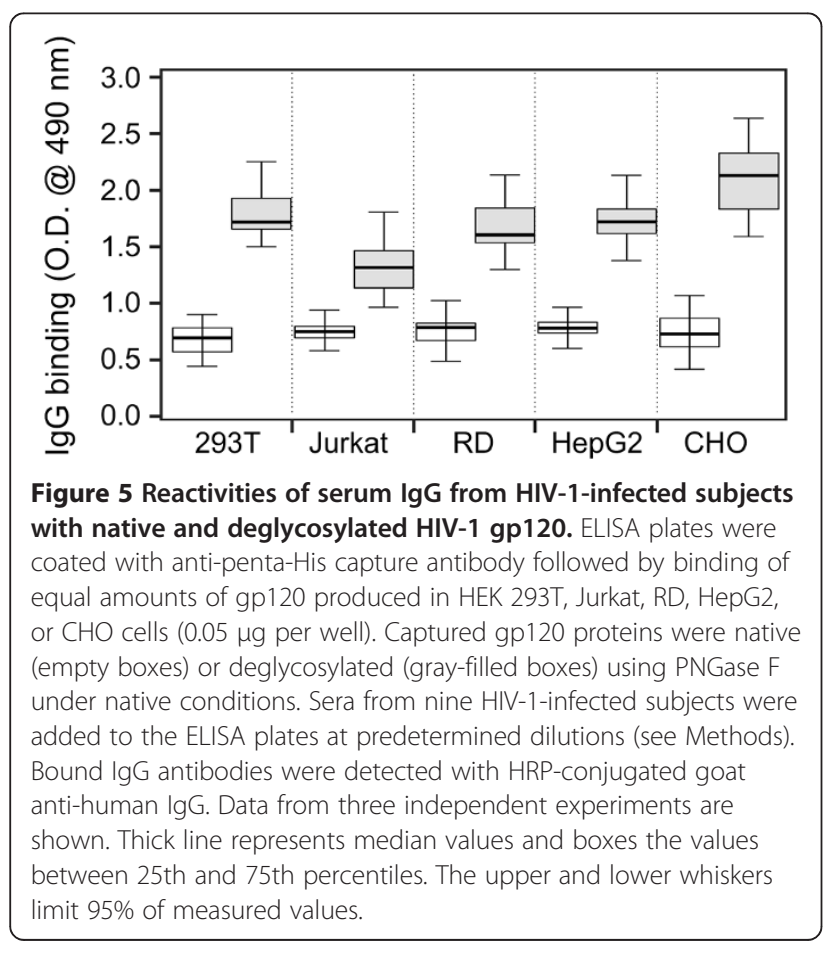

individual gp120 glycoforms by individual sera were higher for Western blot analyses than for dot-blot analyses, indicating that denaturation of gp120 protein could artificially enhance differences in reactivates of serum antibodies, such as detected for sera P2, P4, P6, and P9, although neither reached statistical significance. Furthermore, we used a new ELISA approach that may mimic native conditions, as gp120 oligomers are captured by anti-penta His antibody. The capture antibody serves as a long anchor, thus reducing gp120 contact with hydrophobic surface of ELISA plates. When the recognition of gp120 glycoforms by the same serum antibodies was analyzed by ELISA (Figure 5), the relative binding to individual gp120 differed from the binding detected by Western and dot blots, likely due to gp120 denaturation in the immunoblot assays (Figures 4 and 5). In the Western blot analyses, the best recognized gp120 antigen was that expressed in Jurkat and $\mathrm{CHO}$ cell lines, whereas in dot blot analyses the best recognized antigen was expressed in HepG2 cell line. In contrast, ELISA approach did not detect significant differences among reactivities of all nine sera with individual gp120 preparations. These results suggest a strong bias caused by the choice of the method used to detect the binding of HIV-1 Env-specific antibodies to gp120. 
Similarly to the increased reactivities observed for surfaceexposed-epitope-specific monoclonal antibodies (V3-loopspecific antibodies, Figure 2), partial deglycosylation of gp120 glycoforms significantly enhanced the recognition by serum antibodies (paired $t$ test, $\mathrm{P}<0.001$ ). Furthermore, the differences in recognition of individual gp120 glycoforms by HIV-1-specific polyclonal antibodies were more pronounced after partial deglycosylation (ANOVA, $\mathrm{P}<0.001$ ) compared to untreated gp120 glycoforms (ANOVA, $\mathrm{P}=0.154$ ). Notably, gp120 glycoforms generated by Jurkat $\mathrm{T}$ cells were recognized less well (ANOVA, $\mathrm{P}=0.004$ ) after deglycosylation than the other four glycoforms, although in native conditions all five gp120 glycoforms were recognized similarly (Figure 5). Moreover, antibodies in some of the tested sera exhibited differential reactivity with the gp120 glycans, confirming that gp120 glycoforms produced in specific cell types formed glycan-dependent epitopes.

\section{Cell-specific glycosylation of gp120 affects HIV-1 infection of indicator cells}

To determine the effect of differential gp120 glycosylation on HIV-1 infection, we tested the ability of gp 120 glycoforms generated in different cell types to block SF162 or YU.2 Env-pseudotyped R5 virus infection of TZM-bl reporter cells. As shown in Figure 6, the $\mathrm{IC}_{50}$ for gp120 inhibition of SF162 infection ranged between 0.2 and $0.8 \mu \mathrm{g} / \mathrm{well}$ and for YU.2 infection between 0.1 and $0.5 \mu \mathrm{g} /$ well. The gp120 produced in Jurkat cells most effectively blocked SF162 virus infection, and gp120 produced in CHO cells most effectively blocked YU.2 infection. In contrast, gp120 produced by HEK 293T and RD muscle cells were the least effective in blocking infection by both viruses. We also pre-incubated the indicator cells with each gp120 preparation followed by addition of either SF169 or YU.2 virus and obtained the same level of inhibition as without pre-incubation (Figure 7). Thus, cellspecific glycosylation influenced the ability of recombinant gp120 to block HIV-1 infection of indicator cells.

\section{Discussion}

In this study, we characterized the cell-specific glycoforms of recombinant trimeric consensus B gp120 with respect to their recognition by monoclonal gp120-specific neutralizing antibodies and polyclonal serum antibodies from persons infected with HIV-1 subtype A/C. For this purpose, we used recombinant gp120 expressed in the Nterminal fusion with a 62-amino acid non-glycosylated fragment of mannan-binding lectin to drive gp120 trimerization and secretion and C-terminal His tag and V5 tag $[21,86]$. These modifications of gp120 sequence contain only naturally occurring PNGS present in consensus B gp120, and, because they are the same for all preparations, it is unlikely that protein backbone impacted the observed differences in antibody reactivities. The gp120 glycoforms were differentially recognized by the monoclonal as well as polyclonal antibodies. As the gp120 produced in different cell types had the same amino-acid sequence, it implicates that differential cell type-specific glycosylation of gp120 is the solely cause of the variation in antibody binding. Cell-specific differential glycosylation of Env was reported to affect both epitope availability and epitope formation, as $\mathrm{N}$-glycans contribute to the proper folding of gp120 [87].

The oligomeric consensus B gp120 that we used in this study is glycosylated, depending on the producer cell type, as we reported earlier [21]. We previously showed that human $\mathrm{T}$ cells (Jurkat) produce gp120 with the largest proportion of high-mannose and hybrid $\mathrm{N}$-glycans, whereas HepG2 cells secrete gp120 with more complex $N$-glycans and less high-mannose and hybrid oligosaccharides. The greatest variability in glycosylation of gp120 produced by different cell types was related to the relative contribution of complex and hybrid $\mathrm{N}$-glycans [21]. Based on the relative abundance of high-mannose oligosaccharides, the oligomeric gp120 expressed in Jurkat and RD resembled, at least partially, gp120 isolated from HIV-1 virions produced by peripheral blood mononuclear cells $[56,88]$.
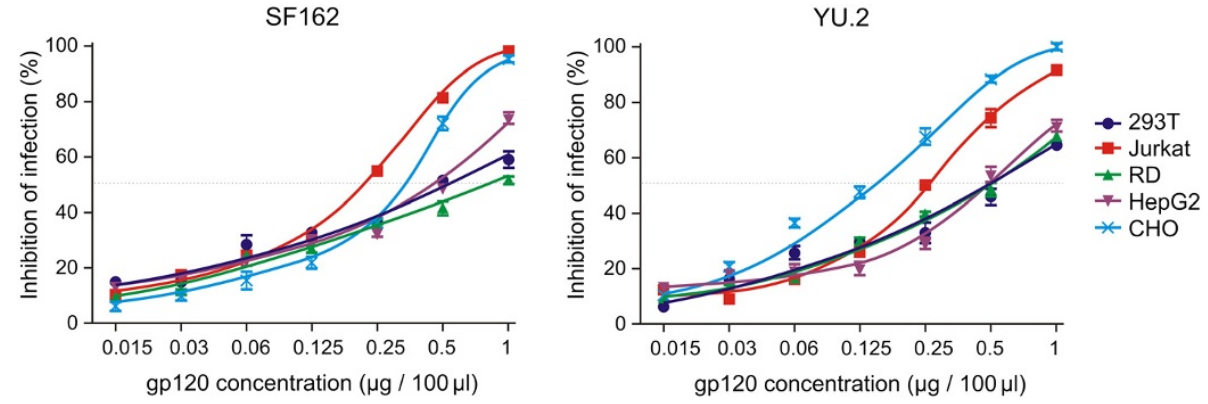

Figure 6 Inhibition of SF162 and YU.2 HIV-1 infectivity by differentially glycosylated recombinant gp120. SF162 or YU.2 pseudoviruses (200 TCID50) together with serially diluted gp120 preparations (1 to $0.015 \mu \mathrm{g} /$ well) were added to TZM-bl reporter cells, and $48 \mathrm{~h}$ later luciferase activity was measured in the cell lysates. Results are expressed as \% inhibition of the infection of TZM-bl reporter cells, with pseudovirus alone considered 100\% infection. Data from three independent experiments are shown. 

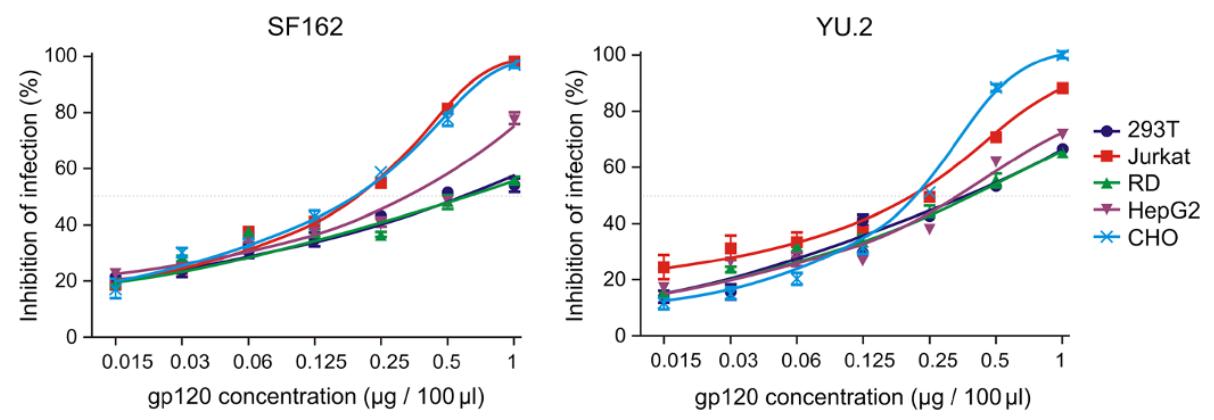

Figure 7 Inhibition of SF162 and YU.2 HIV-1 infectivity by differentially glycosylated recombinant gp120 preincubated with TZM-bI indicator cells. SF162 and YU.2 pseudoviruses were added to TZM-bl reporter cells pre-incubated with serially diluted gp120 preparations (1 to $0.015 \mu \mathrm{g} /$ well). The inhibition of the infectivity was determined and expressed as in Figure 6. Data from three independent experiments are shown.

Here, we extended our previous analyses characterizing differential reactivities of antibodies in sera from HIV-1 clade B-infected individuals [21] to the antibodies in sera from HIV-1 A/C-infected persons and a panel of twelve monoclonal antibodies with five gp120 glycoforms, produced in HEK 293T, Jurkat, RD, HepG2, and $\mathrm{CHO}$ cells. Unlike the antibodies in sera from HIV-1 subtype B-infected patients [21], the antibodies in sera from HIV-1 A/C-infected persons reacted similarly with all gp120 glycoforms. We can speculate that the observed similar reactivities of sera from HIV-1 A/C-infected persons with our set of consensus B gp120 glycoforms are due to preferential recognition of highly conserved epitopes on gp120 which are less affected by differential glycosylation than the clade-specific epitopes recognized by sera from HIV-1 clade B-infected persons. Such epitopes likely include also glycopeptides, as several PNGS and the attached $\mathrm{N}$-glycans are highly conserved in gp120 of HIV$1[37,89]$. Nevertheless, such glycopeptides are probably not generally recognized by broadly neutralizing antibodies, as the frequency of broadly neutralizing glycopeptide-specific antibodies in HIV-1-infected individuals is quite low $[40,44,45,90]$. However, when testing the binding of a panel of monoclonal gp120specific antibodies to gp120 glycoforms, we noted marked differences for some of them. This difference between polyclonal and monoclonal antibodies is probably due to recognition of a broad epitope spectrum by serum antibodies $v s$. single epitope recognized by individual monoclonal antibodies. After partial PNGase Fdriven deglycosylation of gp 120 , the differences in the recognition of individual gp120 glycoforms by serum antibodies increased, probably due to uneven degree of PNGase F-driven deglycosylation and uncovering of several glycan-shielded epitopes. In contrast, the differences in reactivity of monoclonal antibodies with partially deglycosylated gp120 were dependent on localization of the particular epitopes. Specifically, the recognition of gp120 glycoforms by monoclonal antibodies against gp120 V3 loop apex (268 D4, F425 B4e8, 257 D4, 447-52D, 19b) and Mano1, 2Man-linked glycan-specific (2G12) increased markedly. In contrast, partial deglycosylation of gp120 glycoforms differentially impacted the recognition by CD4-binding site-specific antibodies (b12, VRC03, and VRC01): the binding of b12 did not change, VRC03 reactivity decreased, whereas reactivity of VRC01 increased. Recent study using surface plasmon resonance analyses demonstrated that VRC01 binds gp120 with high affinity whereas VRC03 reacts with a 10-fold lower affinity [81]. Thus, VRC01 could act as a partial CD4 agonist in the interaction with gp120, whereas VRC03 does not display this effect [81]. The different VRC03 and VRC01 sensitivity to gp120 deglycosylation observed in this study suggests that VRC03 requires native gp120 glycosylation for effective binding. Due to unchanged proportions in VRC03 reactivities with individual gp120 glycoforms before and after deglycosylation and the observed overall decrease in VRC03 reactivities after deglycosylation, it could be proposed that glycans involved in VRC03 epitope formation are similarly sensitive to PNGase F treatment in all tested gp120 glycoforms. Furthermore, we showed that PG9 and PG16 antibodies, specific to quaternary epitope composed of the gp120 V1/V2 and V3 loops and the associated glycans [40,91], exhibited reduced reactivities with gp120 after partial deglycosylation. Recently, it was reported that changing the glycan profile on the HIV-1 trimer using glycosidase inhibitors or a mutant producer cell line resulted in HIV-1 strainspecific changes in sensitivity to the neutralization activity of PG-family of antibodies [40]. This observation is consistent with disproportional changes in PG9 reactivities with our set of gp120 glycoforms before and after partial glycan removal. The reactivity of another monoclonal antibody tested in our study, PGT121, specific for discontinuous epitope composed of V3 base, the N332 oligomannose glycan and surrounding glycans [47,92], decreased after partial deglycosylation of gp120. This suggests that in contrast to V3 loop which is known to protrude from Env [93], epitopes 
for monoclonal antibodies which are located in various Env cavities are surrounded by glycans which contribute to epitope formation as well as shielding. This conclusion is supported by the observed changes in reactivities of individual monoclonal antibodies before and after partial deglycosylation of gp120 antigens. Comparison of differences in the reactivities of 2G12 and PGT121 with native and PNGase F-treated gp120 glycoforms suggested that conformational changes in V3 base and/ or removal of V1/V2-associated complex glycans could explain the diminished reactivity of PGT121 with PNGase F-treated gp120. Conversely, V3-base glycans or at least some of those glycans involved in binding of 2 G12 (N295, N332) are not affected by PNGase F treatment under native condition $[47,75,76,83,92]$.

Our approach could not distinguish between the glycanvs. protein-associated epitopes, as evidenced by the partially retained reactivities of antibodies recognizing glycans on the partially deglycosylated gp120 (PGT121, 2G12, PG16, PG9) $[40,47,48,83,91]$. However, our tests characterized overall interactions of antibodies with differentially glycosylated gp120 oligomers and discriminated between various glycoforms of gp120 as targets for a panel of well characterized broadly neutralizing monoclonal antibodies. For PGT121, the data suggested that glycans removed by PNGase F under native conditions contributed substantially to PGT121 epitope formation. Moreover, the variability in PGT121 binding to individual gp120 glycoforms after partial deglycosylation suggested that some glycans were still present and involved in epitope formation (Table 1). This interpretation is consistent with our previous finding that complete removal of all glycans requires denaturing conditions [21] as well as with reports of others [76] indicating that some glycans in oligomeric gp140 and gp120/41 Env can be resistant to endoglycosidase cleavage under native conditions.

A partial removal of $\mathrm{N}$-glycans reduced differences in monoclonal antibody binding to native gp120, indicating that differential $\mathrm{N}$-glycosylation affected formation and/or accessibility of Env-specific epitopes, extending previous observations for monoclonal antibody $19 \mathrm{~b}[49,50]$. In contrast, the binding of polyclonal antibodies from sera of subtype A/C HIV-1-infected subjects to native recombinant gp120 glycoproteins was similar for seven of nine sera analyzed by ELISA. However, after partial removal of $N$-glycans binding differences were detected for eight of the nine sera. The most notable increase in reactivity of polyclonal antibodies occurred after deglycosylation of gp120 produced by $\mathrm{CHO}$ and HEK 293T (Figure 5), the cells commonly used for production of vaccine antigens for both experimental and clinical trials, including the first partially successful RV144 trial [38,94]; this observation supports the concept that glycans may shield various Env epitopes [4]. The antibody reactivity after gp120 deglycosylation was least pronounced for gp120 produced by $\mathrm{T}$ cells, the primary host cell type infected by HIV-1. Together, these findings underscore the importance of the cell type for the production of gp120 as a vaccine antigen for eliciting neutralizing antibodies or binding antibodies for antibody-dependent cell-mediated viral inhibition (ADCVI) [95].

Antibodies specific for glycans are associated mostly with IgG2 and IgA2 subclasses, whereas antibodies specific for proteins are predominantly IgG1 and IgA1 isotypes [96]. Thus, for vaccination purposes, the glycosylation of gp120 antigen should be considered in the strategies to induce isotype-specific immune responses in the systemic and mucosal compartments. In this regard, the results of the recent RV144 trial suggest that IgG antibodies targeting V1/V2 gp120 region may have contributed to protection against HIV-1 infection, whereas high levels of Env-specific IgA antibodies in serum may have mitigated the effects of protective antibodies [39,97]. Studies addressing this point are in progress in our laboratories.

To test the hypothesis that differential gp120 glycosylation affects HIV-1 entry into host cells, and consequently infectivity, we analyzed the capacity of recombinant gp 120 glycoforms to inhibit the in vitro infection of reporter cells by two HIV-1 pseudotyped viruses, SF162 and YU.2. The gp120 produced in Jurkat and CHO cells was the most effective at inhibiting infection by both HIV-1 strains. As we reported earlier, the greatest variability in glycosylation of gp120 produced by different cell lines was the relative abundance of complex and high-mannose and hybrid $N$ glycans. Notably, the two gp120 glycoforms from Jurkat and $\mathrm{CHO}$ cell lines contained less complex and hybrid glycans compared to high-mannose glycans [21], resembling the glycan patterns of gp120 on virions [56,88]. Potentially a more direct and biologically relevant way to test the effects of cell-type specific glycosylation of HIV-1 gp120 would be to produce HIV-1 pseudotyped viruses in different cell types and then characterize the differences in their infectivity or sensitivity to broadly neutralizing antibodies. Although we attempted this very challenging approach, we have not succeeded to produce sufficient amount of pseudotyped viruses for our experiments, in contrast to the production of recombinant gp120 in stably transfected cells. Furthermore, it would not be possible to unambiguously attribute all potentially observed changes to cell-type specific glycosylation differences because each cell type may be distinctly sensitive to HIV-1 viral regulatory proteins. The main goal of this study was to assess how the differences in glycosylation, according to the producer cell type, affect recognition by HIV-1 gp120-specific neutralizing and serum antibodies and how they affect interaction with HIV receptors on the reporter cells.

In conclusion, although the production of recombinant gp120 is higher in standard cell types used for 
biotechnology applications (e.g., HEK293), other cell types, such as T cells (Jurkat) produce gp120 antigen with a glycosylation profile resembling that on HIV-1 virions [21]. Jurkat-produced gp120 is well recognized by broadly neutralizing monoclonal antibodies, including the glycan-dependent antibodies PG9 and PGT121, and effectively competes with HIV-1 virions in binding the receptors on reporter cells.

\section{Conclusion}

Together our data revealed that: Recognition of gp120 by V3-loop-specific monoclonal antibodies was hindered by differential glycosylation of gp120; The recognition of CD4-binding sites by VRC03 and VRC01 was distinctly affected by neighboring glycans, with some of them contributing to CD4-binding site formation (VRC03) and others masking the access to CD4-binding site (VRC01); The reactivity of PGT121 (recognizing V3 base, the N332 oligomannose glycan, and surrounding glycans) was reduced after partial $N$-glycan removal, indicating that some $N$-glycans contribute substantially to PGT121 epitope formation; Differences in reactivities of polyclonal serum antibodies from subjects infected with HIV-1 subtype A/C with individual gp120 glycoforms were modest, unlike those observed for subjects infected with HIV-1 subtype B. However, the reactivites increased after partial glycan removal for some gp120 glycoforms; The gp120 produced by $\mathrm{T}$ cells and $\mathrm{CHO}$ cells most effectively blocked infection of reporter cells by HIV-1 virions.

In summary, we show that cell type-specific glycosylation of oligomeric gp120 impacts recognition by serum antibodies from HIV-1-infected subjects and by monoclonal gp120-specific antibodies. Furthermore, cell type-specific glycosylation of gp120 affects its ability to compete with HIV-1 and inhibit infection of TZM-bl reporter cells. This suggests that glycosylation influences the binding of gp120 to cellular receptors/co-receptors and consequently affects the receptor-mediated HIV-1 infection of target cells. Cell type-specific differential glycosylation is characterized by variability in the number and content of complex and high-mannose/hybrid $N$ glycans. Importantly, T cells produced gp120 glycoforms similar to the high content of high-mannose and hybrid glycans found on gp120 of isolated virions [56]. Thus, the glycosylation machinery of cells that produce gp120 shapes its glycosylation and, consequently, impacts antibody reactivity, underscoring the importance of differential gp120 glycosylation in the design of HIV-1 Env vaccines.

\section{Methods}

\section{Human sera}

Serum samples were obtained from subjects infected with HIV-1 subtype $\mathrm{A}$ and/or $\mathrm{C}$ not receiving antiretroviral therapy in the Mbeya Region of Southwestern
Tanzania (HIV Superinfection Study; HISIS), as detailed in previous publications [98-100]. HIV-1 gp120-specific titers of serum IgG antibodies were measured by ELISA, as previously reported [100].

Monoclonal anti-gp120 antibodies 268 D4 (recognizes epitope HIGPGR on V3 loop), F425 B4e8 (recognizes epitope GPGRA on V3 loop), 257 D4 (recognizes epitope KRIHI on V3 loop), 447-52D (recognizes epitope GPGR on V3 loop), 19b (recognizes apex of V3), 2 G12 (recognizes discontinuous epitope composed of clusters of Man 1 1,2Man-linked glycans on the "silent face" of gp120), b12 (recognizes an epitope overlapping the CD4 binding site), PGT121 (recognizes discontinuous epitope composed of V3 base, the N332 oligomannose glycan and surrounding glycans, including a putative V1/V2 complex biantennary glycan), PG9 and PG16 (recognize an epitope consisting of the gp120 V1/V2 and V3 loops and associated glycans), VRC01 and VRC03 (recognize the CD4-binding site) were obtained from the NIH AIDS Research and Reference Reagent Program, Division of AIDS, NIAID, NIH [40,46-54] (Table 1).

\section{Recombinant HIV-1 gp120 preparations}

Human cell lines, including human embryonic kidney cell line HEK 293T, the Jurkat T-cell line, rhabdomyosarcoma cell line $\mathrm{RD}$, and hepatocellular carcinoma cell line HepG2, and Chinese hamster ovary cells (CHO), were obtained from ATCC. Cells were stably transfected with plasmid encoding a codon-optimized consensus B gp120 DNA (GenBank DQ667594 fragment 88-1485) fused Nterminally with cDNA coding for the first 62 amino acids of human mannan-binding lectin (MBL; GeneBank EU596574 fragment 66-252) and C-terminally with His and V5-tag to express the recombinant gp120 in oligomeric form. These modifications of gp120 sequence did not contain any PNGS, and being the same for all preparations have not likely impacted the results. Structure and glycosylation of all five gp120 variants were described previously $[21,86]$. Each cell clone was used to isolate at least $200 \mu \mathrm{g}$ of glycoprotein. The gp120 was purified by affinity nickel-nitrilotriacetic acid (Ni-NTA) agarose under native conditions [21]. The concentration of recombinant glycoproteins was determined by BCA protein assay (Pierce, Rockford, IL) and verified by densitometric analysis of Coomassie blue-stained protein bands after SDS-PAGE (BioRad, Hercules, CA) using Image 1.41a software. The recombinant glycoproteins were aliquoted and stored at $-80^{\circ} \mathrm{C}$.

\section{ELISA and glycan removal from gp120}

To determine the reactivity of monoclonal antibodies or IgG in the sera of HIV-1-infected subjects, ELISA MaxiSorp plates (Nalge Nunc, International, Rochester, NY, USA) were coated overnight with $100 \mu \mathrm{l}$ of $1 \mu \mathrm{g} / \mathrm{ml}$ mouse 
anti-penta-His monoclonal antibody (Qiagen, Valencia, CA, USA). After blocking with SuperBlock (Pierce) supplemented with $0.05 \%$ Tween 20 (SB-T), $0.05 \mu \mathrm{g}$ of native gp120 or partially deglycosylated gp120 were added to each well and incubated overnight at $4^{\circ} \mathrm{C}$. To remove $N$ glycans without gp120 denaturation, treatment with endoglycosidase PNGase F was optimized to reach maximal glycan removal under native conditions as determined by mobility shift on Western blot (7.5 IUB PNGase F per 250 ng of gp120 protein in PBS, incubated for $24 \mathrm{~h}$ ). All assays were performed in duplicate or triplicate, depending on the amount of monoclonal antibodies or sera available. Antibodies were titrated in ELISA using recombinant oligomeric consensus B gp120 produced in HEK 293T cells captured on anti-penta-His monoclonal antibodycoated plates. Assays were performed using three dilutions of monoclonal antibodies or sera corresponding to the linear portion of the titration curve; the middle dilution was used for statistical analyses. Antibodies bound to the gp120 were detected with HRP-labeled goat anti-human IgG (Sigma, St. Louis, MO, USA) followed by the peroxidase substrate $\mathrm{O}$-phenylenediamine- $\mathrm{H} 2 \mathrm{O} 2$. The reaction was stopped with $1 \mathrm{M}$ sulphuric acid and the absorbance measured at $490 \mathrm{~nm}[21,101]$.

To detect possible differences in the binding of native vs. deglycosylated gp120 to the anti-penta His antibodycoated wells on ELISA plate, we compared the binding of anti-V5-tag monoclonal antibody to the gp120 preparations. No differences were detected in the binding of anti-V5-tag.

\section{Inhibition of HIV-1 infectivity by recombinant gp 120}

Serial dilutions ( 1 to $0.015 \mu \mathrm{g} /$ well) of recombinant gp120 in DMEM medium without fetal calf serum were added to $\sim 60 \%$ confluent TZM-bl reporter cells containing reporter cassettes of luciferase and $\beta$-galactosidase [4,102-106]. Either immediately or after $1 \mathrm{~h}$ pre-incubation at $37^{\circ} \mathrm{C}$, an equal volume of YU.2 or SF162 Envpseudotyped R5 virus (200 median tissue culture infective dose, TCID50; corresponding to 150,000 relative luminescence units, RLU) in medium containing $20 \%$ FCS and $30 \mu \mathrm{g} / \mathrm{ml}$ DEAE dextran MW 500,000 (Sigma) was added to each well. The viruses were produced in HEK 293T cells [104]. After $48-\mathrm{h}$ incubation at $37^{\circ} \mathrm{C}$ with $5 \% \mathrm{CO}_{2}$, $75 \mu \mathrm{l}$ of lysis buffer (Promega, Madison, WI, USA) was added to each well, and plates were submitted to three cycles of freeze-thaw. The luciferase activity of the cell lysates $(25 \mu \mathrm{l} /$ well $)$ was measured with a luminometer after the addition of luciferase substrate (Promega). The readings of RLU are directly proportional to the number of infectious virus particles, indicating that the reduction in RLU in wells with gp120 reflects blockade of infection. The results are expressed as \% inhibition of HIV-1 infectivity of TZM-bl target cells, with virus alone considered $100 \%$.

\section{SDS-PAGE/Western blots}

The gp120 preparations were separated by SDS-PAGE under reducing conditions and blotted on PVDF membranes. Membranes were blocked with SB-T and developed with anti-gp120 monoclonal antibody or mounted into Mini-PROTEAN II Multiscreen Apparatus (BioRad) and developed with sera from HIV-1-infected or healthy control subjects. The HIV-1-positive sera were diluted to a final concentration of $0.2 \mu \mathrm{g} / \mathrm{ml}$ gp120-specific IgG, previously determined by ELISA [100]; control sera from healthy subjects were diluted 1:200, which means ten time less diluted than average dilution used for HIV-1 positive sera to exclude non-specific binding. The PVDF membranes were incubated overnight with monoclonal antibodies or sera, and then developed with HRP-conjugated goat anti-human IgG antibody (Sigma). The peroxidasepositive bands were detected with SuperSignal West Pico (Pierce) and visualized by exposure on X-ray film (Kodak) or by using a cooled CCD camera (Roche Diagnostic Corp., Indianapolis, IN, USA). The HRP-conjugated antiV5-tag antibody (Invitrogen, Carlsbad, CA, USA) diluted 1:7,000 in SB-T was used as a positive control.

\section{Dot-blot analysis}

To detect gp120-specific antibodies in sera, $50 \mathrm{ng}$ of recombinant gp120 proteins were applied to each well of a 96-well plate with a PVDF membrane (MultiScreen IP Filer Plate; Millipore, Billerica, MA) and incubated overnight at $4^{\circ} \mathrm{C}$. After blocking with SB-T, sera diluted as described for the Western blot analysis were added, and the plates were incubated overnight at $4^{\circ} \mathrm{C}$. The bound antibodies were detected as described for the Western blot analysis.

\section{Densitometric analysis}

To compare the binding intensity of anti-gp120 antibodies to differentially glycosylated gp120, the densities of bands obtained by Western blot and of dots detected by dot-blot assay were analyzed by ImageJ 1.41a software. Densitometry was performed using calculated background-corrected integrated density over the area adjusted for the largest band or dot of the analyzed gp120.

\section{Statistical analysis}

Differences between groups and statistical significance was determined by utilizing analysis of variance (ANOVA) and paired $t$-test. All statistical analyses were performed using SPSS v. 21 statistical package (IBM Corp., Armonk, NY, USA).

\section{Abbreviations}

BCA: Bicinchoninic acid; Ni-NTA: Nickel-nitrilotriacetic acid; PNGase F: Peptide N4-(N-acetyl-betaglucosaminyl) asparagine amidase F; PVDF: Polyvinylidene difluoride; SB-T: SuperBlock plus 0.05\% Tween 20; SDS-PAGE: Sodium dodecyl sulfate polyacrylamide gel electrophoresis. 


\section{Competing interests}

The authors declare that they have no competing interests.

\section{Authors' contributions}

MR participated in the design of the study, performed the dot blot analyses, participated on the deglycosylation-based ELISA assays and drafting the manuscript, LC participated in the ELISA assays and production of recombinant protein, ZM participated in the inhibition assays and drafting the manuscript, KZ participated in the recombinant gp120 purification, ME participated in the Western blot assays, ZN performed the statistical analysis, SH participated in the protein characterization, MH provided the serum samples, LM was involved in volunteer recruitment and sample collection, RB participated on protein purification, PS participated in drafting the manuscript, JM participated in drafting the manuscript, and JN participated in the study design and drafting the manuscript. All authors read and approved the final manuscript.

\section{Acknowledgements}

This work was supported by the University of Alabama (UAB) CFAR developmental grant (P30AI027767); pilot grant from UAB School of Medicine; UAB Mucosal HIV and Immunobiology Center (DK064400); American Foundation for AIDS Research (amfAR); UAB Immunology, Autoimmunity and Transplantation Pilot Grant; Research Service of the Veterans Administration; National Institutes of Health grants T35 HL007473 and RR-20136; and grant CZ.1.07/2.3.00/20.0164 European Social Fund and LH11046 (Ministry of Education, Youth, and Sport, Czech Republic); and grant LF_2014_020 (Palacky University Olomouc, Czech Republic).

\section{Author details}

'Department of Immunology, Palacky University in Olomouc, 77100 Olomouc, Czech Republic. ${ }^{2}$ Department of Microbiology, University of Alabama at Birmingham, Birmingham, AL 35294, USA. ${ }^{3}$ Department of Infectious Diseases \& Tropical Medicine, Clinic of the University of Munich, Munich, Germany. ${ }^{4}$ NIMR-Mbeya Medical Research Programme, Mbeya, Tanzania. ${ }^{5}$ Department of Medicine, University of Alabama at Birmingham, Birmingham, AL 35294, USA. VA Medical Center, Birmingham, AL 35205, USA. ${ }^{7}$ Institute of Microbiology and Immunology, First Faculty of Medicine, Charles University, 12108 Prague, Czech Republic. ${ }^{8}$ Department of Surgery, University of Alabama at Birmingham, Birmingham, AL 35294, USA.

Received: 23 April 2014 Accepted: 26 July 2014

Published: 1 August 2014

\section{References}

1. Kwong PD, Wyatt R, Robinson J, Sweet RW, Sodroski J, Hendrickson WA: Structure of an HIV gp120 envelope glycoprotein in complex with the CD4 receptor and a neutralizing human antibody. Nature 1998, 393:648-659.

2. Wyatt R, Kwong PD, Desjardins E, Sweet RW, Robinson J, Hendrickson WA Sodroski JG: The antigenic structure of the HIV gp120 envelope glycoprotein. Nature 1998, 393:705-711.

3. Pantophlet R, Burton DR: gp120: target for neutralizing HIV-1 antibodies. Annu Rev Immunol 2006, 24:739-769.

4. Wei X, Decker JM, Wang S, Hui H, Kappes JC, Wu X, Salazar-Gonzalez JF, Salazar MG, Kilby JM, Saag MS, Komarova NL, Nowak MA, Hahn BH, Kwong PD, Shaw GM: Antibody neutralization and escape by HIV-1. Nature 2003, 422:307-312.

5. Arthos J, Cicala C, Martinelli E, Macleod K, Van Ryk D, Wei D, Xiao Z, Veenstra TD, Conrad TP, Lempicki RA, McLaughlin S, Pascuccio M, Gopaul R, McNally J, Cruz CC, Censoplano N, Chung E, Reitano KN, Kottilil S, Goode DJ, Fauci AS: HIV-1 envelope protein binds to and signals through integrin alpha4beta7, the gut mucosal homing receptor for peripheral T cells. Nat Immunol 2008, 9:301-309.

6. Cicala C, Martinelli E, McNally JP, Goode DJ, Gopaul R, Hiatt J, Jelicic K, Kottilil S, Macleod K, O'Shea A, Patel N, Van Ryk D, Wei D, Pascuccio M, Yi L, McKinnon L, Izulla P, Kimani J, Kaul R, Fauci AS, Arthos J: The integrin alpha4beta7 forms a complex with cell-surface CD4 and defines a T-cell subset that is highly susceptible to infection by HIV-1. Proc Natl Acad SCi U S A 2009, 106:20877-20882

7. Hioe CE, Bastiani L, Hildreth JE, Zolla-Pazner S: Role of cellular adhesion molecules in HIV type 1 infection and their impact on virus neutralization. AIDS Res Hum Retroviruses 1998, 14(Suppl 3):S247-S254.
8. Hioe CE, Hildreth JE, Zolla-Pazner S: Enhanced HIV type 1 neutralization by human anti-glycoprotein 120 monoclonal antibodies in the presence of monoclonal antibodies to lymphocyte function-associated molecule 1. AIDS Res Hum Retroviruses 1999, 15:523-531.

9. Simek MD, Rida W, Priddy FH, Pung P, Carrow E, Laufer DS, Lehrman JK, Boaz M, Tarragona-Fiol T, Miiro G, Birungi J, Pozniak A, McPhee DA, Manigart O, Karita E, Inwoley A, Jaoko W, DeHovitz J, Bekker L-G, Pitisuttithum P, Paris R, Walker LM, Poignard P, Wrin T, Fast PE, Burton DR, Koff WC: Human immunodeficiency virus type 1 elite neutralizers: individuals with broad and potent neutralizing activity identified by using a high-throughput neutralization assay together with an analytical selection algorithm. J Virol 2009, 83:7337-7348.

10. Doria-Rose NA, Klein RM, Manion MM, O'Dell S, Phogat A, Chakrabarti B, Hallahan CW, Migueles SA, Wrammert J, Ahmed R, Nason M, Wyatt RT, Mascola JR, Connors M: Frequency and phenotype of human immunodeficiency virus envelope-specific B cells from patients with broadly cross-neutralizing antibodies. J Virol 2009, 83:188-199.

11. Walker LM, Simek MD, Priddy F, Gach JS, Wagner D, Zwick MB, Phogat SK, Poignard $P$, Burton DR: A limited number of antibody specificities mediate broad and potent serum neutralization in selected HIV-1 infected individuals. PLOS Pathog 2010, 6:e1001028.

12. Stamatatos L, Morris L, Burton DR, Mascola JR: Neutralizing antibodies generated during natural HIV-1 infection: good news for an HIV-1 vaccine? Nat Med 2009, 15:866-870.

13. Fauci AS: 25 years of HIV. Nature 2008, 453:289-290.

14. Balzarini J: Targeting the glycans of gp120: a novel approach aimed at the Achilles heel of HIV. Lancet Infect Dis 2005, 5:726-731.

15. Letvin NL, Rao SS, Dang V, Buzby AP, Korioth-Schmitz B, Dombagoda D, Parvani JG, Clarke RH, Bar L, Carlson KR, Kozlowski PA, Hirsch VM, Mascola JR, Nabel GJ: No evidence for consistent virus-specific immunity in simian immunodeficiency virus-exposed, uninfected rhesus monkeys. J Virol 2007 81:12368-12374.

16. Robinson HL: HIV/AIDS vaccines: 2007. Clin Pharmacol Ther 2007, 82:686-693.

17. Zhu X, Borchers C, Bienstock RJ, Tomer KB: Mass spectrometric characterization of the glycosylation pattern of HIV-gp120 expressed in CHO cells. Biochemistry 2000, 39:11194-11204.

18. Go EP, Chang Q, Liao HX, Sutherland LL, Alam SM, Haynes BF, Desaire H: Glycosylation site-specific analysis of clade C HIV-1 envelope proteins. J Proteome Res 2009, 8:4231-4242.

19. Go EP, Hewawasam G, Liao HX, Chen H, Ping LH, Anderson JA, Hua DC, Haynes BF, Desaire $\mathrm{H}$ : Characterization of glycosylation profiles of HIV-1 transmitted/founder envelopes by mass spectrometry. J Virol 2011, 85:8270-8284

20. Raska M, Novak J: Involvement of envelope-glycoprotein glycans in HIV-1 biology and infection. Arch Immunol Ther Exp (Warsz) 2010, 58:191-208.

21. Raska M, Takahashi K, Czernekova L, Zachova K, Hall S, Moldoveanu Z, Elliot MC, Wilson L, Brown R, Jancova D, Barnes S, Vrbkova J, Tomana M, Smith PD, Mestecky J, Renfrow MB, Novak J: Glycosylation patterns of HIV-1 gp120 depend on the type of expressing cells and affect antibody recognition. J Biol Chem 2010, 285:20860-20869.

22. Mizuochi T, Matthews TJ, Kato M, Hamako J, Titani K, Solomon J, Feizi T: Diversity of oligosaccharide structures on the envelope glycoprotein gp120 of human immunodeficiency virus 1 from the lymphoblastoid cell line H9. Presence of complex-type oligosaccharides with bisecting $\mathrm{N}$-acetylglucosamine residues. J Biol Chem 1990, 265:8519-8524.

23. Mizuochi T, Spellman MW, Larkin M, Solomon J, Basa LJ, Feizi T: Structural characterization by chromatographic profiling of the oligosaccharides of human immunodeficiency virus (HIV) recombinant envelope glycoprotein gp120 produced in Chinese hamster ovary cells. Biomed Chromatogr 1988, 2:260-270.

24. Mizuochi T, Spellman MW, Larkin M, Solomon J, Basa LJ, Feizi T: Carbohydrate structures of the human-immunodeficiency-virus (HIV) recombinant envelope glycoprotein gp120 produced in Chinese-hamster ovary cells. Biochem J 1988, 254:599-603.

25. Reitter JN, Means RE, Desrosiers RC: A role for carbohydrates in immune evasion in AIDS. Nat Med 1998, 4:679-684.

26. Reitter JN, Desrosiers RC: Identification of replication-competent strains of simian immunodeficiency virus lacking multiple attachment sites for $\mathrm{N}$-linked carbohydrates in variable regions 1 and 2 of the surface envelope protein. J Virol 1998, 72:5399-5407. 
27. Ho YS, Abecasis AB, Theys K, Deforche K, Dwyer DE, Charleston M, Vandamme AM, Saksena NK: HIV-1 gp120 N-linked glycosylation differs between plasma and leukocyte compartments. Virol J 2008, 5:14.

28. Go EP, Irungu J, Zhang Y, Dalpathado DS, Liao HX, Sutherland LL, Alam SM, Haynes BF, Desaire H: Glycosylation site-specific analysis of HIV envelope proteins (JR-FL and CON-S) reveals major differences in glycosylation site occupancy, glycoform profiles, and antigenic epitopes' accessibility. J Proteome Res 2008, 7:1660-1674.

29. Clapham PR, McKnight A: HIV-1 receptors and cell tropism. Br Med Bull 2001, 58:43-59.

30. Cicala C, Arthos J, Fauci AS: HIV-1 envelope, integrins and co-receptor use in mucosal transmission of HIV. J Trans/ Med 2011, 9(Suppl 1):S2.

31. Decker JM, Bibollet-Ruche F, Wei X, Wang S, Levy DN, Wang W, Delaporte E, Peeters M, Derdeyn CA, Allen S, Hunter E, Saag MS, Hoxie JA, Hahn BH, Kwong PD, Robinson JE, Shaw GM: Antigenic conservation and immunogenicity of the HIV coreceptor binding site. J Exp Med 2005, 201:1407-1419.

32. Salazar-Gonzalez JF, Bailes E, Pham KT, Salazar MG, Guffey MB, Keele BF, Derdeyn CA, Farmer P, Hunter E, Allen S, Manigart O, Mulenga J, Anderson JA, Swanstrom R, Haynes BF, Athreya GS, Korber BT, Sharp PM, Shaw GM, Hahn BH: Deciphering human immunodeficiency virus type 1 transmission and early envelope diversification by single-genome amplification and sequencing. $J$ Virol 2008, 82:3952-3970.

33. Pollakis G, Kang S, Kliphuis A, Chalaby MI, Goudsmit J, Paxton WA: N-linked glycosylation of the HIV type-1 gp120 envelope glycoprotein as a major determinant of CCR5 and CXCR4 coreceptor utilization. J Biol Chem 2001, 276:13433-13441.

34. McCaffrey RA, Saunders C, Hensel M, Stamatatos L: N-linked glycosylation of the V3 loop and the immunologically silent face of gp120 protects human immunodeficiency virus type 1 SF162 from neutralization by anti-gp120 and anti-gp41 antibodies. J Virol 2004, 78:3279-3295.

35. Clevestig P, Pramanik L, Leitner T, Ehrnst A: CCR5 use by human immunodeficiency virus type 1 is associated closely with the gp120 V3 loop N-linked glycosylation site. J Gen Virol 2006, 87:607-612.

36. Wolk T, Schreiber M: N-Glycans in the gp120 V1/V2 domain of the HIV-1 strain NL4-3 are indispensable for viral infectivity and resistance against antibody neutralization. Med Microbiol Immunol 2006, 195:165-172.

37. Huang X, Jin W, Hu K, Luo S, Du T, Griffin GE, Shattock RJ, Hu Q: Highly conserved HIV-1 gp120 glycans proximal to CD4-binding region affect viral infectivity and neutralizing antibody induction. Virology 2012, 423:97-106.

38. Rerks-Ngarm S, Pitisuttithum P, Nitayaphan S, Kaewkungwal J, Chiu J, Paris R, Premsri N, Namwat C, de Souza M, Adams E, Benenson M, Gurunathan S, Tartaglia J, McNeil JG, Francis DP, Stablein D, Birx DL, Chunsuttiwat S, Khamboonruang C, Thongcharoen P, Robb ML, Michael NL, Kunasol P, Kim $J \mathrm{H}$ : Vaccination with ALVAC and AIDSVAX to prevent HIV-1 infection in Thailand. N Engl J Med 2009, 361:2209-2220.

39. Haynes BF, Gilbert PB, McElrath MJ, Zolla-Pazner S, Tomaras GD, Alam SM, Evans DT, Montefiori DC, Karnasuta C, Sutthent R, Liao HX, DeVico AL, Lewis GK, Williams C, Pinter A, Fong Y, Janes H, DeCamp A, Huang Y, Rao M, Billings E, Karasavvas N, Robb ML, Ngauy V, de Souza MS, Paris R, Ferrari G, Bailer RT, Soderberg KA, Andrews C, et al: Immune-correlates analysis of an HIV-1 vaccine efficacy trial. N Engl J Med 2012, 366:1275-1286.

40. Doores KJ, Burton DR: Variable loop glycan dependency of the broad and potent HIV-1-neutralizing antibodies PG9 and PG16. J Virol 2010, 84:10510-10521.

41. Walker LM, Huber M, Doores KJ, Falkowska E, Pejchal R, Julien JP, Wang SK, Ramos A, Chan-Hui PY, Moyle M, Mitcham JL, Hammond PW, Olsen OA, Phung P, Fling S, Wong CH, Phogat S, Wrin T, Simek MD, Koff WC, Wilson IA, Burton DR, Poignard P: Broad neutralization coverage of HIV by multiple highly potent antibodies. Nature 2011, 477:466-470.

42. Kwong PD, Mascola JR, Nabel GJ: The changing face of HIV vaccine research. Journal of the International Aids Society 2012, 15:17407.

43. Platt EJ, Gomes MM, Kabat D: Kinetic mechanism for HIV-1 neutralization by antibody $2 \mathrm{G} 12$ entails reversible glycan binding that slows cell entry. Proc Natl Acad Sci U S A 2012, 109:7829-7834.

44. Pejchal R, Doores K, Walker LM, Khayat R, Huang PS, Wang SK, Stanfield RL, Julien JP, Ramos A, Crispin M, Depetris R, Katpally U, Marozsan A, Cupo A, Maloveste S, Liu Y, McBride R, Ito Y, Sanders RW, Ogohara C, Paulson JC, Feizi T, Scanlan CN, Wong CH, Moore JP, Olson WC, Ward AB, Poignard P, Schief WR, Burton DR, et al: A potent and broad neutralizing antibody recognizes and penetrates the HIV glycan shield. Science 2011, 334:1097-1103.
45. Walker LM, Phogat SK, Chan-Hui PY, Wagner D, Phung P, Goss JL, Wrin T, Simek MD, Fling S, Mitcham JL, Lehrman JK, Priddy FH, Olsen OA, Frey SM, Hammond PW, Kaminsky S, Zamb T, Moyle M, Koff WC, Poignard P, Burton DR: Broad and potent neutralizing antibodies from an African donor reveal a new HIV-1 vaccine target. Science 2009, 326:285-289.

46. Pejchal R, Walker LM, Stanfield RL, Phogat SK, Koff WC, Poignard P, Burton $D R$, Wilson IA: Structure and function of broadly reactive antibody PG16 reveal an $\mathrm{H} 3$ subdomain that mediates potent neutralization of HIV-1. Proc Natl Acad Sci U S A 2010, 107:11483-11488.

47. Julien JP, Sok D, Khayat R, Lee JH, Doores KJ, Walker LM, Ramos A, Diwanji DC, Pejchal R, Cupo A, Katpally U, Depetris RS, Stanfield RL, McBride R, Marozsan AJ, Paulson JC, Sanders RW, Moore JP, Burton DR, Poignard P, Ward AB, Wilson IA: Broadly neutralizing antibody PGT121 allosterically modulates CD4 binding via recognition of the HIV-1 gp120 V3 base and multiple surrounding glycans. PLoS Pathog 2013, 9:e1003342.

48. Calarese DA, Scanlan CN, Zwick MB, Deechongkit S, Mimura Y, Kunert R, Zhu P, Wormald MR, Stanfield RL, Roux KH, Kelly JW, Rudd PM, Dwek RA, Katinger H, Burton DR, Wilson IA: Antibody domain exchange is an immunological solution to carbohydrate cluster recognition. Science 2003, 300:2065-2071.

49. Eggink D, Melchers M, Wuhrer M, van Montfort T, Dey AK, Naaijkens BA, David KB, Le Douce V, Deelder AM, Kang K, Olson WC, Berkhout B, Hokke $\mathrm{CH}$, Moore JP, Sanders RW: Lack of complex N-glycans on HIV-1 envelope glycoproteins preserves protein conformation and entry function. Virology 2010, 401:236-247.

50. Kong L, Sheppard NC, Stewart-Jones GB, Robson CL, Chen H, Xu X, Krashias G, Bonomelli C, Scanlan CN, Kwong PD, Jeffs SA, Jones IM, Sattentau QJ: Expression-system-dependent modulation of HIV-1 envelope glycoprotein antigenicity and immunogenicity. J Mol Biol 2010, 403:131-147.

51. Gorny MK, Xu JY, Gianakakos V, Karwowska S, Williams C, Sheppard HW, Hanson CV, Zolla-Pazner S: Production of site-selected neutralizing human monoclonal antibodies against the third variable domain of the human immunodeficiency virus type 1 envelope glycoprotein. Proc Natl Acad Sci U S A 1991, 88:3238-3242.

52. Pantophlet R, Aguilar-Sino RO, Wrin T, Cavacini LA, Burton DR: Analysis of the neutralization breadth of the anti-V3 antibody F425-B4e8 and re-assessment of its epitope fine specificity by scanning mutagenesis. Virology 2007, 364:441-453.

53. Gorny MK, Conley AJ, Karwowska S, Buchbinder A, Xu JY, Emini EA, Koenig S, Zolla-Pazner S: Neutralization of diverse human immunodeficiency virus type 1 variants by an anti-V3 human monoclonal antibody. J Virol 1992, 66:7538-7542.

54. Burton DR, Barbas CF 3rd, Persson MA, Koenig S, Chanock RM, Lerner RA: A large array of human monoclonal antibodies to type 1 human immunodeficiency virus from combinatorial libraries of asymptomatic seropositive individuals. Proc Natl Acad Sci U S A 1991, 88:10134-10137.

55. Pantophlet $\mathrm{R}$, Wang $\mathrm{M}$, Aguilar-Sino RO, Burton DR: The human immunodeficiency virus type 1 envelope spike of primary viruses can suppress antibody access to variable regions. J Virol 2009, 83:1649-1659.

56. Bonomelli C, Doores KJ, Dunlop DC, Thaney V, Dwek RA, Burton DR, Crispin M, Scanlan CN: The glycan shield of HIV is predominantly oligomannose independently of production system or viral clade. PLoS One 2011, 6:e23521.

57. Julien JP, Lee PS, Wilson IA: Structural insights into key sites of vulnerability on HIV-1 Env and influenza HA. Immunol Rev 2012, 250:180-198.

58. Derdeyn CA, Decker JM, Bibollet-Ruche F, Mokili JL, Muldoon M, Denham SA, Heil ML, Kasolo F, Musonda R, Hahn BH, Shaw GM, Korber BT, Allen S, Hunter E: Envelope-constrained neutralization-sensitive HIV-1 after heterosexual transmission. Science 2004, 303:2019-2022.

59. Li H, Chien PC Jr, Tuen M, Visciano ML, Cohen S, Blais S, Xu CF, Zhang HT, Hioe CE: Identification of an $\mathrm{N}$-linked glycosylation in the $\mathrm{C} 4$ region of HIV-1 envelope gp120 that is critical for recognition of neighboring CD4 T cell epitopes. J Immunol 2008, 180:4011-4021.

60. Kothe DL, Decker JM, Li Y, Weng Z, Bibollet-Ruche F, Zammit KP, Salazar MG, Chen Y, Salazar-Gonzalez JF, Moldoveanu Z, Mestecky J, Gao F, Haynes BF, Shaw GM, Muldoon M, Korber BT, Hahn BH: Antigenicity and immunogenicity of HIV-1 consensus subtype B envelope glycoproteins. Virology 2007, 360:218-234.

61. Huang X, Barchi JJ Jr, Lung FD, Roller PP, Nara PL, Muschik J, Garrity RR: Glycosylation affects both the three-dimensional structure and antibody binding properties of the HIV-1IIIB GP120 peptide RP135. Biochemistry 1997, 36:10846-10856. 
62. Wain LV, Bailes E, Bibollet-Ruche F, Decker JM, Keele BF, Van Heuverswyn F, Li Y, Takehisa J, Ngole EM, Shaw GM, Peeters M, Hahn BH, Sharp PM: Adaptation of HIV-1 to its human host. Mol Biol Evol 2007, 24:1853-1860

63. Reitz MS Jr, Hall L, Robert-Guroff M, Lautenberger J, Hahn BM, Shaw GM, Kong LI, Weiss SH, Waters D, Gallo RC, Blattner WA: Viral variability and serum antibody response in a laboratory worker infected with HIV type 1 (HTLV type IIIB). AIDS Res Hum Retroviruses 1994, 10:1143-1155.

64. Rong R, Gnanakaran S, Decker JM, Bibollet-Ruche F, Taylor J, Sfakianos JN, Mokili JL, Muldoon M, Mulenga J, Allen S, Hahn BH, Shaw GM, Blackwell JL, Korber BT, Hunter E, Derdeyn CA: Unique mutational patterns in the envelope alpha 2 amphipathic helix and acquisition of length in gp120 hypervariable domains are associated with resistance to autologous neutralization of subtype $C$ human immunodeficiency virus type 1. J Virol 2007, 81:5658-5668.

65. Keele BF, Giorgi EE, Salazar-Gonzalez JF, Decker JM, Pham KT, Salazar MG, Sun C, Grayson T, Wang S, Li H, Wei X, Jiang C, Kirchherr JL, Gao F, Anderson JA, Ping LH, Swanstrom R, Tomaras GD, Blattner WA, Goepfert PA, Kilby JM, Saag MS, Delwart EL, Busch MP, Cohen MS, Montefiori DC, Haynes BF, Gaschen B, Athreya GS, Lee HY, et al: Identification and characterization of transmitted and early founder virus envelopes in primary HIV-1 infection. Proc Natl Acad Sci U S A 2008, 105:7552-7557.

66. Burton DR, Ahmed R, Barouch DH, Butera ST, Crotty S, Godzik A, Kaufmann DE, McElrath MJ, Nussenzweig MC, Pulendran B, Scanlan CN, Schief WR, Silvestri G, Streeck H, Walker BD, Walker LM, Ward AB, Wilson IA, Wyatt R: A blueprint for HIV vaccine discovery. Cell Host Microbe 2012, 12:396-407.

67. Koff WC: HIV vaccine development: challenges and opportunities towards solving the HIV vaccine-neutralizing antibody problem. Vaccine 2012, 30:4310-4315.

68. Moore PL, Gray ES, Wibmer CK, Bhiman JN, Nonyane M, Sheward DJ, Hermanus T, Bajimaya S, Tumba NL, Abrahams MR, Lambson BE, Ranchobe N, Ping L, Ngandu N, Abdool Karim Q, Abdool Karim SS, Swanstrom RI, Seaman MS, Williamson C, Morris L: Evolution of an HIV glycan-dependent broadly neutralizing antibody epitope through immune escape. Nat Med 2012, 18:1688-1692.

69. Wang W, Nie J, Prochnow C, Truong C, Jia Z, Wang S, Chen XS, Wang Y: A systematic study of the $\mathrm{N}$-glycosylation sites of HIV-1 envelope protein on infectivity and antibody-mediated neutralization. Retrovirology 2013, 10:14.

70. Gorny MK, Xu JY, Karwowska S, Buchbinder A, Zolla-Pazner S: Repertoire of neutralizing human monoclonal antibodies specific for the V3 domain of HIV-1 gp120. J Immunol 1993, 150:635-643.

71. Bell CH, Pantophlet R, Schiefner A, Cavacini LA, Stanfield RL, Burton DR, Wilson IA: Structure of antibody F425-B4e8 in complex with a V3 peptide reveals a new binding mode for HIV-1 neutralization. J Mol Biol 2008, 375:969-978.

72. Stanfield RL, Gorny MK, Williams C, Zolla-Pazner S, Wilson IA: Structural rationale for the broad neutralization of HIV-1 by human monoclonal antibody 447-52D. Structure 2004, 12:193-204.

73. Burke V, Williams C, Sukumaran M, Kim SS, Li H, Wang XH, Gorny MK, Zolla-Pazner S, Kong XP: Structural basis of the cross-reactivity of genetically related human anti-HIV-1 mAbs: implications for design of V3-based immunogens. Structure 2009, 17:1538-1546.

74. Moore JP, Trkola A, Korber B, Boots LJ, Kessler JA 2nd, McCutchan FE, Mascola J, Ho DD, Robinson J, Conley AJ: A human monoclonal antibody to a complex epitope in the $\mathrm{V} 3$ region of gp120 of human immunodeficiency virus type 1 has broad reactivity within and outside clade B. J Virol 1995, 69:122-130.

75. Scanlan CN, Pantophlet R, Wormald MR, Saphire EO, Calarese D, Stanfield R Wilson IA, Katinger H, Dwek RA, Burton DR, Rudd PM: The carbohydrate epitope of the neutralizing anti-HIV-1 antibody 2G12. Adv Exp Med Biol 2003, 535:205-218.

76. Sanders RW, Venturi M, Schiffner L, Kalyanaraman R, Katinger H, Lloyd KO, Kwong PD, Moore JP: The mannose-dependent epitope for neutralizing antibody $2 \mathrm{G} 12$ on human immunodeficiency virus type 1 glycoprotein gp120. J Virol 2002, 76:7293-7305.

77. Mouquet H, Scharf L, Euler Z, Liu Y, Eden C, Scheid JF, Halper-Stromberg A Gnanapragasam PN, Spencer DI, Seaman MS, Schuitemaker H, Feizi T, Nussenzweig MC, Bjorkman PJ: Complex-type N-glycan recognition by potent broadly neutralizing HIV antibodies. Proc Natl Acad Sci U S A 2012 109:E3268-E3277.

78. Pancera M, Shahzad-UI-Hussan S, Doria-Rose NA, McLellan JS, Bailer RT, Dai K, Loesgen S, Louder MK, Staupe RP, Yang Y, Zhang B, Parks R, Eudailey J,
Lloyd KE, Blinn J, Alam SM, Haynes BF, Amin MN, Wang LX, Burton DR, Koff WC, Nabel GJ, Mascola JR, Bewley CA, Kwong PD: Structural basis for diverse $\mathrm{N}$-glycan recognition by HIV-1-neutralizing V1-V2-directed antibody PG16. Nat Struct Mol Biol 2013, 20:804-813.

79. Zhou T, Xu L, Dey B, Hessell AJ, Van Ryk D, Xiang SH, Yang X, Zhang MY, Zwick MB, Arthos J, Burton DR, Dimitrov DS, Sodroski J, Wyatt R, Nabel GJ, Kwong PD: Structural definition of a conserved neutralization epitope on HIV-1 gp120. Nature 2007, 445:732-737.

80. Wu X, Zhou T, O'Dell S, Wyatt RT, Kwong PD, Mascola JR: Mechanism of human immunodeficiency virus type 1 resistance to monoclonal antibody B12 that effectively targets the site of CD4 attachment. J Virol 2009, 83:10892-10907

81. Wu X, Yang Z-Y, Li Y, Hogerkorp C-M, Schief WR, Seaman MS, Zhou T, Schmidt SD, Wu L, Xu L, Longo NS, McKee K, O'Dell S, Louder MK, Wycuff DL, Feng $Y$, Nason M, Doria-Rose N, Connors M, Kwong PD, Roederer M, Wyatt RT, Nabel GJ, Mascola JR: Rational Design of Envelope Identifies Broadly Neutralizing Human Monoclonal Antibodies to HIV-1. Science 2010, 329:856-861.

82. Li Y, O'Dell S, Walker LM, Wu X, Guenaga J, Feng Y, Schmidt SD, McKee K, Louder MK, Ledgerwood JE, Graham BS, Haynes BF, Burton DR, Wyatt RT, Mascola JR: Mechanism of neutralization by the broadly neutralizing HIV-1 monoclonal antibody VRC01. J Virol 2011, 85:8954-8967.

83. Doores KJ, Fulton Z, Huber M, Wilson IA, Burton DR: Antibody 2G12 recognizes di-mannose equivalently in domain- and nondomainexchanged forms but only binds the HIV-1 glycan shield if domain exchanged. J Virol 2010, 84:10690-10699.

84. Crooks ET, Tong T, Osawa K, Binley JM: Enzyme digests eliminate nonfunctional Env from HIV-1 particle surfaces, leaving native Env trimers intact and viral infectivity unaffected. J Virol 2011, 85:5825-5839.

85. Means RE, Desrosiers RC: Resistance of native, oligomeric envelope on simian immunodeficiency virus to digestion by glycosidases. J Virol 2000, 74:11181-11190.

86. Raska M, Moldoveanu Z, Novak J, Hel Z, Novak L, Bozja J, Compans RW, Yang C, Mestecky J: Delivery of DNA HIV-1 vaccine to the liver induces high and long-lasting humoral immune responses. Vaccine 2008, 26:1541-1551.

87. Li Y, Luo L, Rasool N, Kang CY: Glycosylation is necessary for the correct folding of human immunodeficiency virus gp120 in CD4 binding. J Virol 1993, 67:584-588.

88. Doores KJ, Bonomelli C, Harvey DJ, Vasiljevic S, Dwek RA, Burton DR, Crispin M, Scanlan CN: Envelope glycans of immunodeficiency virions are almost entirely oligomannose antigens. Proc Natl Acad Sci U S A 2010, 107:13800-13805.

89. Hemming A, Gram GJ, Bolmstedt A, Losman B, Hansen JE, Ricksten A, Olofsson S: Conserved N-linked oligosaccharides of the C-terminal portion of human immunodeficiency virus type $1 \mathrm{gp} 120$ and viral susceptibility to neutralizing antibodies. Arch Virol 1996, 141:2139-2151.

90. Trkola A, Purtscher M, Muster T, Ballaun C, Buchacher A, Sullivan N, Srinivasan K, Sodroski J, Moore JP, Katinger H: Human monoclonal antibody 2G12 defines a distinctive neutralization epitope on the gp120 glycoprotein of human immunodeficiency virus type 1. J Virol 1996, 70:1100-1108.

91. Doria-Rose NA, Georgiev I, O'Dell S, Chuang GY, Staupe RP, McLellan JS, Gorman J, Pancera M, Bonsignori M, Haynes BF, Burton DR, Koff WC, Kwong PD, Mascola JR: A short segment of the HIV-1 gp120 V1/V2 region is a major determinant of resistance to V1/V2 neutralizing antibodies. J Virol 2012, 86:8319-8323.

92. Zhu J, O'Dell S, Ofek G, Pancera M, Wu X, Zhang B, Zhang Z, Mullikin JC, Simek M, Burton DR, Koff WC, Shapiro L, Mascola JR, Kwong PD: Somatic populations of PGT135-137 HIV-1-neutralizing antibodies identified by 454 pyrosequencing and bioinformatics. Front Microbiol 2012, 3:315.

93. Huang CC, Tang M, Zhang MY, Majeed S, Montabana E, Stanfield RL, Dimitrov DS, Korber B, Sodroski J, Wilson IA, Wyatt R, Kwong PD: Structure of a V3-containing HIV-1 gp120 core. Science 2005, 310:1025-1028.

94. Flynn NM, Forthal DN, Harro CD, Judson FN, Mayer KH, Para MF: Placebo-controlled phase 3 trial of a recombinant glycoprotein 120 vaccine to prevent HIV-1 infection. J Infect Dis 2005, 191:654-665.

95. Raux M, Finkielsztejn L, Salmon-Ceron D, Bouchez H, Excler JL, Dulioust E, Grouin JM, Sicard D, Blondeau C: IgG subclass distribution in serum and various mucosal fluids of HIV type 1-infected subjects. AIDS Res Hum Retroviruses 2000, 16:583-594.

96. Xu W, Santini PA, Sullivan JS, He B, Shan M, Ball SC, Dyer WB, Ketas TJ, Chadburn A, Cohen-Gould L, Knowles DM, Chiu A, Sanders RW, Chen K, Cerutti 
A: HIV-1 evades virus-specific lgG2 and IgA responses by targeting systemic and intestinal B cells via long-range intercellular conduits. Nat Immunol 2009, 10:1008-1017.

97. Mestecky J, Wei Q, Alexander R, Raska M, Novak J, Moldoveanu Z: Humoral Immune Responses to HIV in the Mucosal Secretions and Sera of HIV-Infected Women. Am J Reprod Immunol 2014, 71:600-607.

98. Riedner G, Hoffmann O, Rusizoka M, Mmbando D, Maboko L, Grosskurth H, Todd J, Hayes R, Hoelscher M: Decline in sexually transmitted infection prevalence and HIV incidence in female barworkers attending prevention and care services in Mbeya Region, Tanzania. Aids 2006, 20:609-615.

99. Hoffmann O, Zaba B, Wolff B, Sanga E, Maboko L, Mmbando D, von Sonnenburg F, Hoelscher M: Methodological lessons from a cohort study of high risk women in Tanzania. Sex Transm Infect 2004, 80(Suppl 2):ii69-ii73.

100. Mestecky J, Wright PF, Lopalco L, Staats HF, Kozlowski PA, Moldoveanu Z, Alexander RC, Kulhavy R, Pastori C, Maboko L, Riedner G, Zhu Y, Wrinn T, Hoelscher M: Scarcity or absence of humoral immune responses in the plasma and cervicovaginal lavage fluids of heavily HIV-1-exposed but persistently seronegative women. AIDS Res Hum Retroviruses 2011, 27:469-486.

101. Raska M, Elliott MC, Hall S, Czernekova L, Zachova K, Moldoveanu Z, Brown R, Mestecky J, Novak J: HIV-1 gp120 glycosylation is cell type-specific and influences reactivity with HIV-1-specific antibodies. In Centennial Retrovirus Meeting: 29 Apr-04 May 2010; Prague. Edited by Rene D, Jiri H, Skalka AM, Jan S. Medimond; 2010:55-59.

102. Alexander R, Mestecky J: Neutralizing antibodies in mucosal secretions: IgG or IgA? Curr HIV Res 2007, 5:588-593.

103. Li M, Gao F, Mascola JR, Stamatatos L, Polonis VR, Koutsoukos M, Voss G Goepfert P, Gilbert P, Greene KM, Bilska M, Kothe DL, Salazar-Gonzalez JF, Wei X, Decker JM, Hahn BH, Montefiori DC: Human immunodeficiency virus type 1 env clones from acute and early subtype B infections for standardized assessments of vaccine-elicited neutralizing antibodies. J Virol 2005, 79:10108-10125.

104. Montefiori DC: Measuring HIV neutralization in a luciferase reporter gene assay. Methods Mol Biol 2009, 485:395-405.

105. Ochsenbauer C, Kappes JC: New virologic reagents for neutralizing antibody assays. Curr Opin HIV AIDS 2009, 4:418-425.

106. Wei X, Decker JM, Liu H, Zhang Z, Arani RB, Kilby JM, Saag MS, Wu X, Shaw GM, Kappes JC: Emergence of resistant human immunodeficiency virus type 1 in patients receiving fusion inhibitor (T-20) monotherapy. Antimicrob Agents Chemother 2002, 46:1896-1905.

doi:10.1186/1742-6405-11-23

Cite this article as: Raska et al.: Differential glycosylation of envelope gp120 is associated with differential recognition of HIV-1 by virus-specific antibodies and cell infection. AIDS Research and Therapy 2014 11:23.

\section{Submit your next manuscript to BioMed Central and take full advantage of:}

- Convenient online submission

- Thorough peer review

- No space constraints or color figure charges

- Immediate publication on acceptance

- Inclusion in PubMed, CAS, Scopus and Google Scholar

- Research which is freely available for redistribution 